\title{
Redox Proteomics and Platelet Activation: Understanding the Redox Proteome to Improve Platelet Quality for Transfusion
}

\author{
Giona Sonego ${ }^{1}$, Mélanie Abonnenc ${ }^{1}$, Jean-Daniel Tissot ${ }^{1,2}$, Michel Prudent ${ }^{1}$ and \\ Niels Lion ${ }^{1,2, *}$ \\ 1 Transfusion Interrégionale Croix Rouge Suisse SA, Laboratoire de Recherche sur les Produits Sanguins, \\ Route de la Corniche 2, 1066 Epalinges, Switzerland; giona.sonego@itransfusion.ch (G.S.); \\ melanie.abonnenc@itransfusion.ch (M.A.); jean-daniel.tissot@itransfusion.ch (J.-D.T.); \\ michel.prudent@itransfusion.ch (M.P.) \\ 2 Faculté de Biologie et de Médecine, Université de Lausanne, CH-1011 Lausanne, Switzerland \\ * Correspondence: niels.lion@itransfusion.ch; Tel.: +4-121-333-1671
}

Academic Editor: David Sheehan

Received: 16 December 2016; Accepted: 7 February 2017; Published: 11 February 2017

\begin{abstract}
Blood banks use pathogen inactivation (PI) technologies to increase the safety of platelet concentrates (PCs). The characteristics of PI-treated PCs slightly differ from those of untreated PCs, but the underlying reasons are not well understood. One possible cause is the generation of oxidative stress during the PI process. This is of great interest since reactive oxygen species (ROS) act as second messengers in platelet functions. Furthermore, there are links between protein oxidation and phosphorylation, another mechanism that is critical for cell regulation. Current research efforts focus on understanding the underlying mechanisms and identifying new target proteins. Proteomics technologies represent powerful tools for investigating signaling pathways involving ROS and post-translational modifications such as phosphorylation, while quantitative techniques enable the comparison of the platelet resting state versus the stimulated state. In particular, redox cysteine is a key player in platelet activation upon stimulation by different agonists. This review highlights the experiments that have provided insights into the roles of ROS in platelet function and the implications for platelet transfusion, and potentially in diseases such as inflammation and platelet hyperactivity. The review also describes the implication of redox mechanism in platelet storage considerations.
\end{abstract}

Keywords: activation; aggregation; blood products; phosphorylation; platelet function; platelets; reactive oxygen species; redox cysteine; transfusion

\section{Introduction}

Platelets are anucleate cells that are involved not only in hemostasis but also in many inflammatory processes [1,2]. Platelets are critical in transfusion practices. In the context of transfusion, platelet concentrates (PCs) are labile blood products used either prophylactically to prevent bleeding or therapeutically to stop bleeding (Figure 1) [3]. Cold storage of platelets induces modifications in platelet membranes. Cold storage also results in novel structures that are related to the associations of specific sugar structures that lead to the elimination of platelet after transfusion within the Kupffer cells of the liver [4]. Thus, PCs are mainly stored under agitation at room temperature (RT) until use for a maximum of five or seven days, depending on institutional specifications. Because there is a risk of bacterial growth during RT storage, as well as the danger of other emerging (undetected) pathogens, several countries now use pathogen inactivation technologies (PITs) to ensure a safer product [5]. Indeed, since the introduction of PITs adverse transfusion reactions and transfusion-transmitted 
infections have decreased dramatically [6]. Currently, there are two main commercially available PITs: INTERCEPT ${ }^{\mathrm{TM}}$ (Cerus, Concord, MA, USA) and Mirasol ${ }^{\circledR}$ (Terumo BCT, Lakewood, CO, USA). A third PIT, THERAFLEX UV (Macopharma, Tourcoing, France), is being tested in a clinical phase III study. PITs exploit the anucleate nature of platelets and irreversibly crosslink or damage genetic material, thereby inactivating bacteria, viruses, and parasites [6].

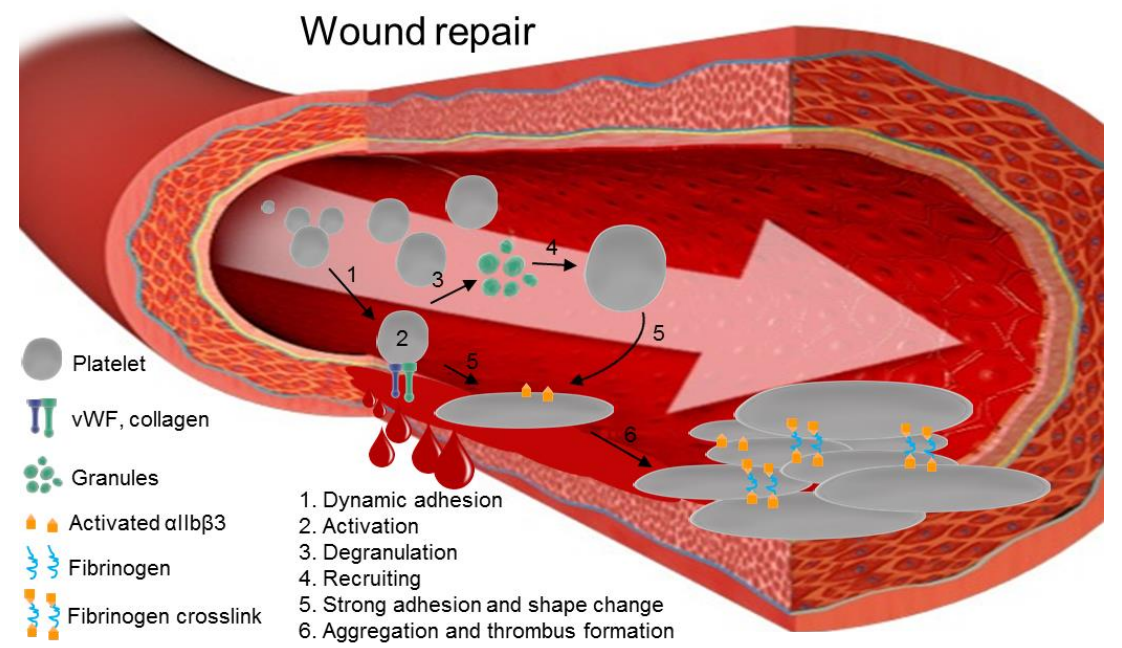

Figure 1. The steps in platelet activation and aggregation in thrombus formation after wounding. Damage to the epithelial wall of a vein exposes vWF and collagen. Receptors on platelets, such as glycoprotein Ib-IX (GP-Ib-IX), $\alpha \mathrm{IIb} \beta 3$, and glycoprotein VI (GPVI), reversibly bind to newly-exposed proteins (1). This induces internal signaling, leading to platelet activation (2). Platelets undergo degranulation (3) and secrete chemokines, including ADP, serotonin, ions like $\mathrm{Ca}^{2+}$, and other molecules that recruit additional platelets (4). Once activated platelets are bound on the endothelial wall, they progressively and definitively stick on the vein, changing their shape (5). Activated platelets form crosslinks via fibrinogen bridges between $\alpha \mathrm{IIb} \beta 3$ proteins, forming the thrombus (6).

While PITs have proven their efficacy for reducing pathogens in PCs [7], in vitro assays show that PI-treated PCs have altered functionality and accelerated metabolism. Importantly, treated PCs exhibit a higher platelet pre-activation level and are less reactive to stimuli, thus showing lower efficacy than untreated PCs [8-10]. In addition, a recent study reported that microparticulation was significantly increased in treated PCs as they approached their expiration date [11]. At the clinical level, Kerckhoffs et al. observed that inactivated platelets show decreased clinical effectiveness based on corrected count increment (CCI) after $1 \mathrm{~h}[12,13]$. The result is an increased need for PCs. Nevertheless, Corash et al. expressed reservations about the use of PI-treated PCs [14]. The Cazenave [15] and Lozano groups [16] found no significant differences in the clinical effectiveness of PI-treated versus untreated PCs. Differences in data collection methods make it difficult to compare studies, so the clinical relevance of PITs in platelet function remains unclear in terms of CCI and bleeding time $[17,18]$. To summarize, there is a general consensus that PITs have a negative impact on the in vitro characteristics of PCs, but the reasons are not completely known or understood.

Oxidative stress is one possible cause of the functional changes in platelets that are observed in vitro after PIT treatment $[19,20]$. Indeed, amotosalen and riboflavin, which are the photosensitizers in INTERCEPT TM and Mirasol ${ }^{\circledR}$, respectively, can sensitize oxygen molecules via type I or II mechanisms following excitation by UV light and thereby generate reactive oxygen species (ROS), like ${ }^{1} \mathrm{O}_{2}, \mathrm{O}_{2}{ }^{-}$, $\mathrm{H}_{2} \mathrm{O}_{2}$, and $\mathrm{OH}$ [21,22]. Furthermore, UV light alone can induce the formation of ROS [23], showing that $\mathrm{UV}(\mathrm{B})$ itself can play an active role in platelet functionality in vitro [24]. As a consequence, over time, an ROS imbalance could potentially impact platelet function in both reversible and irreversible ways.

Several diseases that involve platelets are accompanied or characterized by increased levels of ROS in their early stages. For instance, atherosclerosis, which occludes coronary vessels, involves 
platelet adhesion, which is enhanced by redox signaling [25]. Immune thrombocytopenia, which leads to decreased platelet production and increased platelet clearance, is also related to oxidative stress [26]. Atherothrombosis is the main risk factor in type I and II diabetes due to hyperactive platelets, and enhanced intracellular production of ROS is among the markers of these diseases [27]. Nevertheless, for more than 20 years ROS have not only been shown to be deleterious, but also to actively regulate platelet signaling and activation [28]. The results from recent redox proteomic approaches, together with classical approaches, highlight the importance of a complex redox cellular system that can influence the resting platelet state [29]. PITs could interfere with this state due to their intrinsic nature.

PITs are expected to alter the resting oxidative state of platelets by increasing both oxidation and redox second messenger signaling, for example in apoptosis [30] and in the platelet activation/aggregation pathway [31,32]. To clarify this, the redox proteome in platelets must be better understood. Redox proteomics provide tools that can describe these phenomena and that can be used to monitor both reversible and irreversible modifications of the protein oxidation state that play roles in biological structures and cell functionality [33]. Accordingly, redox proteomics can help define a given cellular state, such as aging, activation, and the pre-apoptotic state, and provide a better understanding of platelet functionality. Moreover, clinicians lack insights into the in vivo behavior of treated platelets after transfusion; thus, in the age of precision medicine, a better characterization of PCs could improve transfusion results.

The aim of this review is to provide a state-of-the-art description of the role of ROS in platelets, with an emphasis on cysteine, which is a key amino acid in redox signaling. The review describes how PITs are thought to damage the platelet proteome based on mass spectrometry results. It also analyzes platelet signaling that involves ROS in order to better understand the impact of reversible oxidation. Within the context of transfusion, the review gives an overview of the cysteine redox state and its crosstalk with phosphorylation. Finally, discussions are opened on the actual debate on platelet processing/storage strategies.

\section{Alterations and Oxidation of Platelet Proteins}

Platelet storage lesions affect cell metabolism, activation and morphology [34-36]. Such lesions have a non-negligible impact on proteins [37]. Indeed, the use of a combination of multiple proteomic strategies has revealed a network of proteins involved in platelet activation, cytoskeletal reorganization, vesicle trafficking, and apoptosis, all of which undergo storage-related changes [37]. To limit storage-induced stress on platelets, efforts are being made to continuously optimize storage conditions, e.g., by making changes in the composition of plastic bags and additive solutions as well as by changing the temperature and agitation conditions. PITs have also been found to exacerbate platelet storage lesions [37]. Even though platelets are enucleated cells, the platelets remain capable of synthesizing some proteins [36,38-40]. Indeed, much attention has been focused on the platelet proteome, which involves more than 4000 proteins to date [41], in order to better define the impact of PITs on platelet function.

Marrocco et al. used a two dimensional-gel electrophoresis (2D-GE) approach to analyze changes in platelet proteins after riboflavin/UVB treatment. They found significant changes in the expression of some relevant proteins, including plekstrin, $\beta$-actin, ATP synthase, and the nuclear chloride channel [42]. Our laboratory used a similar approach and found significant changes in the expression of two proteins, DJ-1 and glutaredoxin-5, after platelets were subjected to

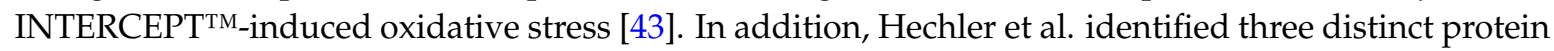
pattern variations (involving plekstrin, integrin-linked protein kinase, and the cytoplasmic protein NCK2) in INTERCEPT ${ }^{\mathrm{TM}}$-treated platelets, also by using 2D-GE [44]. Thiele et al. used a gel-free approach in which liquid chromatography was coupled to tandem mass spectrometry to analyze buffy coat-derived PCs. They identified changes in a number of proteins after PI treatment. The most important and irreversible alterations, observed on days 1 and 5, were alterations in the expression levels of the PEAR-1, CXCR4, and CLIC4 proteins [45]. 
These changes in protein expression can probably be attributed, at least in part, to protein oxidation processes such as carbonylation. Supporting this notion, Johnson et al. found higher levels of carbonylation in Mirasol ${ }^{\circledR}$-treated PCs compared to untreated buffy coat-derived PCs [20]. Carbonyl insertion into proteins occurs mainly by three mechanisms: amino acid backbone scission, amino acid side chain cleavage, and side chain ketone or aldehyde formation by metal catalysis [46]. Diverse amino acid side chains can undergo oxidation, with lysine, arginine, proline, threonine, and tryptophan among the most sensitive amino acids [47-49]. Oxygen insertion can drive an important electronic change and affect the amino acid structure. In addition, singlet oxygen can drive inter-amino acid reactions that induce the formation of covalent bridges and influence the tertiary structure of proteins [50].

Carbonylation constitutes an intracellular biomarker of oxidative stress that is often associated with aging and diseases. It is one of the most common types of protein damage, notably because it is an irreversible and stable modification that is usually not affected by sample preparation. During aging, antioxidant cell defenses decrease [51], allowing ROS to interact with DNA, RNA, lipids, and proteins. In the same way, diseases accompanied by oxidative stress raise the carbonylation level in the platelet proteome [52]. In general, carbonylated proteins are either repaired by specific enzymes or processed by the proteolysis machinery. These oxidation reactions can induce partial protein unfolding, thereby exposing hydrophobic regions and leading to the loss of the protein's primary function and to aggregation $[20,53]$. However, while protein carbonylation is generally considered to be deleterious and associated with diseases [47], it might well be one of the final steps of the oxidation chain caused by ROS in platelet activation that participates in redox signaling [54].

Aging and disease might not be the only causes of protein carbonylation in cells. Upon platelet activation, the platelet proteome undergoes a profound transformation, and the level of protein carbonylation increases [55]. For instance, thrombin and arachidonic acid stimulation enhance the carbonylation of platelet proteins [56]. This suggests the involvement of ROS in platelet activation, leading to carbonylation. Although a few proteins show changes after PI treatment [45], the findings are difficult to interpret; the findings may partially explain the changes in platelet functionality that are observed in in vitro tests. In addition, the global impact of carbonylation on the proteome is relatively low. It is reasonable to hypothesize that subtle changes might occur during PIT treatment or even during platelet activation in vivo, such as regulation of the redox state.

\section{The Role of ROS in Platelet Function}

\subsection{Platelet Activation Pathways Stimulate ROS Production}

There are a few agonist-induced activation pathways that produce ROS, including the collagen, thrombin, and arachidonic acid activation pathways. The $2^{\prime}, 7^{\prime}$-dichlorodihydrofluorescein diacetate $\left(\mathrm{H}_{2}\right.$ DCFDA) assay is most often used to measure the ROS level inside cells. After cytosolic hydrolysis, $\mathrm{H}_{2}$ DCFDA can be oxidized into $2^{\prime}, 7^{\prime}$-dichlorofluorescein (DCF), which fluoresces at $520 \mathrm{~nm}$. $\mathrm{H}_{2}$ DCFDA is currently used in flow cytometry analyses for direct and reliable relative quantification of intracellular ROS. After cytosolic hydrolysis, DCFH can be oxidized into DCF, which fluoresces at $520 \mathrm{~nm}$. $\mathrm{H}_{2}$ DCFDA is currently used in flow cytometry analyses for direct and reliable relative quantification of intracellular ROS. $\mathrm{H}_{2}$ DCFDA is currently used in flow cytometry, allowing direct and reliable relative quantification of intracellular ROS. One of the main advantages of this technique is that it allows the rapid detection of ROS, so that short-lived oxidative imbalance can be measured. Using an $\mathrm{H}_{2}$ DCFDA-based assay, Bakdash and Williams found compartmentalization of ROS production that depended on the stimulated receptor [57]. Stimulation of platelets with convulxin, an agonist peptide targeting the collagen glycoprotein VI (GPVI) receptor, induces intraplatelet ROS production, while thrombin, a GPIb $\alpha$ and PARs agonist, induces mainly extracellular ROS formation. Indeed, upon thrombin activation, Bakdash and William found significantly decreased P-selectin exposure and $\alpha \operatorname{Ilb} \beta 3$ activation using a combination of the extracellular antioxidants superoxide dismutase 
(SOD) and catalase [57]. Carrim et al. showed that a concerted mechanism involving GPIb $\alpha$ and PAR-4 receptors, the latter of which has a low affinity for thrombin, is involved in generating thrombin-derived ROS [58]. Indeed, specific cleavage of the thrombin-binding site on GPIb $\alpha$ by the Nk protease at Tyr276-Asp277 abolishes ROS generation under thrombin stimulation. In addition, in the presence of the Nk protease, stimulation with PAR-4 agonists such as PAR4-AP and AYPGKF- $\mathrm{NH}_{2}$ substantially decreases the platelet aggregation percentage [58]. Upon collagen stimulation, ROS generation is significantly decreased by inhibiting focal adhesion tyrosine kinase in the GPIb $\alpha$-PAR4 downstream cascade [59], while the main receptor, PAR-1, which has a high affinity for thrombin, seems to activate platelets via ROS-independent pathways. Recently, cyclophilin A (CyPA), a bidirectional regulator of the $\alpha \mathrm{IIb} \beta 3$ receptor, was identified as a crucial component in the generation of ROS under thrombin stimulation [60]. CyPA interacts with the p47phox subunit to modulate the assembly of the cytoplasmic membrane NAD(P)H complex, which generates ROS [61]. Furthermore, flow cytometry shows that thrombin-induced ROS formation and platelet activation via $\alpha \operatorname{IIb} \beta 3$, which was quantified using an antibody to PAC-1 (the first procaspase activating compound), are significantly reduced in CyPA-deficient mice $\left(\mathrm{CyPA}^{-/-}\right)[60]$.

Collagen is probably one of the most potent agonists that stimulate ROS-mediated platelet activation [62]. GPVI, a platelet-specific collagen receptor, has been identified as a receptor that regulates platelet redox [63]. Arthur et al. showed by immunoprecipitation that the ligation of the GPVI/FcR $\gamma$ needs the TNF adapter receptor 4 (TRAF4) to act downstream to enhance ROS production by NADPH oxidase (NOX) [64]. Indeed, the bridging interaction of TRAF4 with the intracellular GPVI peptide and the p47phox subunit of NOX allows transduction of the stimuli, which culminates in the formation of the thrombus. TRAF4 also interacts with other proteins, such as Hic-5, which is linked to the Src family tyrosine kinase Lyn, in collagen-mediated signal propagation [65]. Moreover, the same group identified two distinct phases of ROS production. ROS were measured at an early stage in the presence of a spleen tyrosine kinase (Syk) inhibitor, BAY61-3606. However, 15 to $20 \mathrm{~min}$ later, the second wave of ROS was not observed in the presence of the inhibitor. They concluded that collagen-mediated platelet activation involves two pathways, a Syk-independent pathway and a Syk-dependent pathway. This suggests a potential role for ROS in phosphorylation events (see Section 5).

At a later stage, during thrombus formation, oxidative stress leads to enhanced phospholipase A2 enzyme activity, resulting in the release of arachidonic acid into the cytoplasm [66]. Activated platelets trigger the conversion of arachidonic acid into a potent platelet aggregation mediator, thromboxane $\mathrm{A}_{2}\left(\mathrm{TXA}_{2}\right)$. TXA 2 has a pivotal role in that it stabilizes the thrombus and promotes thrombus growth by recruiting additional platelets. During the conversion of arachidonic acid into $\mathrm{TXA}_{2}$, cyclooxigenase 1 (COX1) catalyzes the formation of the intermediate prostaglandin $\mathrm{H}_{2}$ and generates ROS as a by-product [67]. Interestingly, other agonists, such as ADP, soluble CD40 ligand, and other chemokines, do not detectably increase ROS [31]. This also indicates that ROS production occurs at a specific time and via a specific pathway during platelet activation.

\subsection{NADPH Oxidase}

The role of ROS as messengers or mediators of cell signaling is currently widely accepted [68]. Several platelet-related pathways that produce and release ROS have been identified, including the NOX, COX1, and xanthine pathways [69]. Whereas the latter two pathways produce ROS as a by-product, the primary function of the NOX pathway is to modulate redox-sensitive signaling by converting molecular oxygen into the oxygen superoxide anion, $\mathrm{O}_{2}^{-\cdot}$ (Figure 2). This involves the inactivation of phosphotyrosine phosphatases, the activation of certain transcription factors, and the modulation of ion channels [70]. The NOX pathway not only produces ROS, but it can also be activated by ROS. Indeed, one hallmark of this pathway is that it responds to a large range of stimuli, including chemical, physical, environmental, and biological factors [71]. The NOX complex is activated by cytoplasmic $47^{\text {phox }}$ phosphorylation, which causes it to localize to the cell membrane. Finazzi-Agrò et al. found that the NOX complex is an essential component for efficient activation in 
platelets, and they demonstrated the release of $\mathrm{H}_{2} \mathrm{O}_{2}$ upon platelet activation using scopoletin in a fluorescence assay [72]. NOX-derived ROS participate in the core stress-response signaling pathway via the MAPK and c-Jun $\mathrm{NH}_{2}$-terminal kinases [71]. Several groups have investigated the role of ROS production during platelet activation using $\mathrm{NOX}^{-/-}$mouse cells. Recently, Delaney et al. showed that enzymatic NOX1 and NOX2 complexes are not part of the same platelet activation pathway [73]. Walsh et al. demonstrated the role of NOX1 in optimal p38MAPK signaling and in subsequent TXA 2 production in C57BL6/J background mice [74]. Inhibition of NOX1, either by chemicals such as 2-acetylphenothiazine, diphenylene iodonium, or apocynin, or by the specific peptide-antagonist gp91, decreases calcium mobilization, which is associated with a decrease in platelet $\alpha \mathrm{Ilb} \beta 3$ activation, aggregation, and thrombus formation under high shear flow conditions [31,74,75]. On the other hand, NOX2 knock-out potently inhibits ROS generation under collagen peptide stimulation conditions [73]. In addition, performing the laser-induced arterial thrombosis assay in $\mathrm{NOX}^{-/}$mice showed an effect on thrombus formation but not on bleeding time [73]. These data suggest that ROS are crucial for efficient hemostasis, while platelet adhesion is less ROS-dependent. In the same way, ROS scavengers are able to reduce the platelet response to stimuli, highlighting the importance of ROS as secondary messengers [31,76].

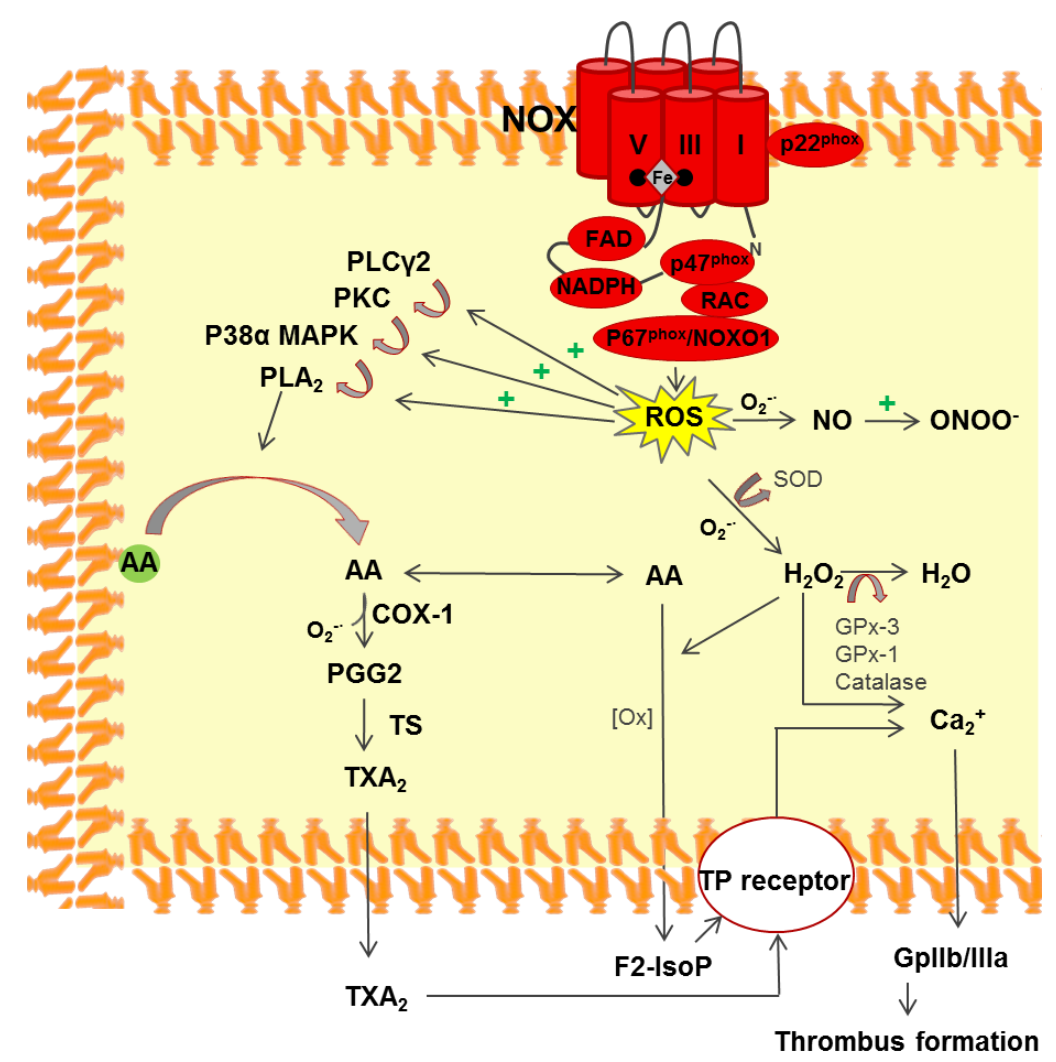

Figure 2. The role of NOX (NOX1 and/or NOX2) in thrombus formation via ROS production. Increased intracellular ROS production enhances $(+)$ redox internal signaling. ROS potentiate the PLC $\gamma /$ PKC/MAPKp38 signaling cascade, thereby inducing phospholipase A2 (PLA $)$ activation via (arrows) phosphorylation. PLA 2 catalyzes the hydrolysis of the phospholipid sn2-acyl bond at the membrane, releasing arachidonic acid (AA) into the cytoplasm. AA can either be converted by COX1 into prostaglandin G2 (PGG2), an intermediate in the synthesis of thromboxane A2 (TxA2), or it can be oxidized by peroxides to form F2 isoprostane (F2-IsoP). Both can bind the prostanoid TP receptor during thrombosis/hemostasis. $\mathrm{O}_{2}{ }^{-}$can be converted into the more membrane permeable $\mathrm{H}_{2} \mathrm{O}_{2}$ by superoxide dismutase (SOD). $\mathrm{H}_{2} \mathrm{O}_{2}$ acts as a second messenger in various cellular signaling pathways, and it also induces $\mathrm{Ca}^{2+}$ mobilization. $\mathrm{Ca}^{2+}$ mobilization precede the glycoprotein GPIIb/IIIa (or $\alpha \mathrm{IIb} \beta 3$ ) affinity modulation to fibrinogen binding. Alternatively, $\mathrm{O}_{2}{ }^{-\cdot}$ reacts with $\mathrm{NO}$, leading to reactive nitrogen species such as $\mathrm{ONOO}^{-}$. 


\subsection{Platelet Activation via ROS}

Platelet activation is a complex biological process that involves several signaling pathways $[77,78]$. Early work in this field established that platelet activation occurs via ROS stimulation, but the underlying regulatory mechanisms and the target molecules were not well known. The $\mathrm{O}_{2}^{-\cdot}$ generated by NOX can be converted by SOD to $\mathrm{H}_{2} \mathrm{O}_{2}$, which is more stable and acts as a second messenger, or to a hydroxyl radical $(\mathrm{OH})$ [28]. $\mathrm{O}_{2}^{-\cdot}$ can also stimulate F2-isoprostane and interact with nitric oxide, which downregulates platelet activation to form $\mathrm{ONOO}^{-}$(Figure 2). To confirm the role of $\mathrm{H}_{2} \mathrm{O}_{2}$ in platelet activation, Dayal et al. overexpressed glutathione-peroxidase-1 in mice [79] and found significantly reduced platelet activation in response to thrombin stimulation due to the scavenging of $\mathrm{H}_{2} \mathrm{O}_{2}$ by this peroxidase.

Apparently intra-platelet ROS generation is related to $\alpha \mathrm{IIb} \beta 3$ regulation, rather than to granule secretion or changes in the shape of platelets [31]. The work of Jang et al. has provided insights into the collagen/platelet aggregation pathway (Figure 3) [80]. After stimulation of GPVI with collagen, the Src kinase family of proteins initiates a signaling cascade by phosphorylating the Fc-receptor $\gamma$-chain, which recruits the tyrosine kinase Syk. Syk activates the linker of activated T cells, which induces the formation of a signaling complex with phospholipase $\mathrm{C} \gamma(\mathrm{PLC} \gamma-2)$. The subsequent phosphorylation of PLC $\gamma-2$ triggers the hydrolysis of the membrane phospholipid $\mathrm{PIP}_{2}$ into soluble inositol trisphosphate $\left(\mathrm{IP}_{3}\right)$ and other signaling molecules. Lastly, once it is bound to the $\mathrm{IP}_{3}$ receptor (InsP3R, a membrane glycoprotein that acts as a calcium channel), $\mathrm{IP}_{3}$ induces calcium ion mobilization in the cytosol. Jang et al. identified a redox cysteine switch-off in SHP-2 that plays an important role in regulating the tyrosine kinases that target the Syk and PLC $\gamma-2$ complex [80]. They indirectly measured cysteine sulfenylation (i.e., $\mathrm{R}-\mathrm{SOH}$ ) by ligation with thiol-reactive biotin to confirm the inhibitory effect of $\mathrm{H}_{2} \mathrm{O}_{2}$ on SHP-2. Furthermore, Krötz et al. showed that the addition of SOD to collagen-stimulated platelets reduced the release of ADP into the supernatant, thus decreasing platelet recruitment [32]. This could indicate that $\mathrm{O}_{2}{ }^{-\cdot}$ participates in platelet recruitment, while $\mathrm{H}_{2} \mathrm{O}_{2}$ (formed by the reduction of $\mathrm{O}_{2}{ }^{-\cdot}$ by SOD) is not involved. Taken together, these studies strongly suggest that ROS partially regulate the activation of integrin $\alpha \mathrm{Ilb} \beta 3$ and the subsequent aggregation of platelets and thrombus growth (Figure 1).

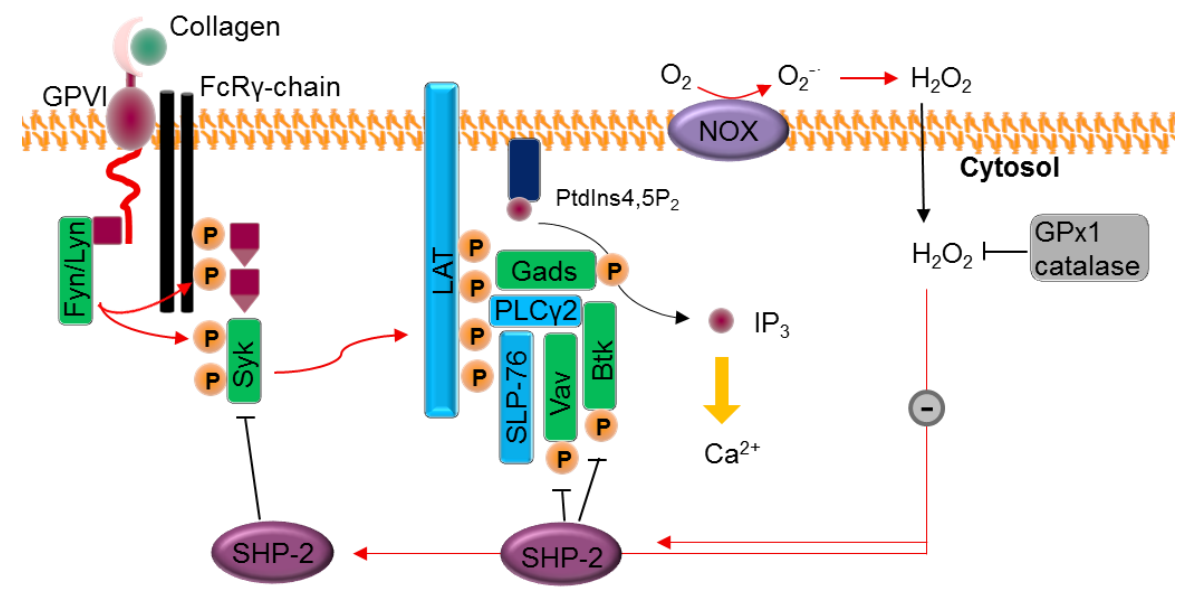

Figure 3. $\mathrm{Ca}^{2+}$ mobilization upon stimulation with collagen agonists. Collagen induces the assembly of NOX complexes at the membrane. $\mathrm{O}_{2}{ }^{-}$is converted by SOD into the thiol effector and membrane permeable (black arrow) $\mathrm{H}_{2} \mathrm{O}_{2}$, which reversibly switches off the SHP-2 phosphatase SHP-2 cysteine oxidation inhibits its phosphatase function (black $\mathrm{T}$ bars) and results in enhanced (red arrows) kinases Syk, Vav1, and Btk phosphorylation, essential for the activation of membrane complexes such as PLC $\gamma$-2 and LAT and inducing $\mathrm{IP}_{3}$ release in the cytosol. $\mathrm{IP}_{3}$ acts on the calcium channel, mobilizing $\mathrm{Ca}^{2+}$ (yellow arrow). Adapted from reference [31], courtesy of Tong-Shin Chang. 
ROS second messengers also negatively regulate platelet function by inducing the shedding of the platelet GPIb $\alpha$ ectodomain and thus reducing vWF binding [81]. When platelets that were previously incubated with antioxidants such as $\mathrm{N}$-acetyl cysteine or DTT are stimulated with collagen, thrombin or A23187, shedding of the ectodomain is partially inhibited. ADAM17/TACE enzyme activation, which occurs via a p38MAPK-dependent mechanism that is related to intraplatelet oxidative stress, enables the release of the GPIb $\alpha$ ectodomain [82]. Strong stimulation of platelets and ROS enhance the formation of the mitochondrial permeability transition (mPT) pore, allowing cytoplasmic calcium to enter mitochondria. In turn, this stimulates agonist-initiated phosphatidylserine exposure at the membrane [83]. It appears that thiol groups that are able to cross-link play a critical role in MPT pore formation, explaining the involvement of ROS. Indeed, McStay et al. showed that under conditions of oxidative stress, adenine nucleotide translocase can form an intramolecular cross-link between C160 and C257, blocking ATP/ADP exchange at the mitochondrial membrane and enhancing the formation of the $\mathrm{mPT}$ pore [84]. In the context of transfusion medicine, PCs subjected to Mirasol ${ }^{\circledR}$ treatment showed increased ROS production during storage and specifically on days 2 and 5 of storage [20]. These findings may explain the activation state of inactivated platelets: the redox signaling pathways could be overstimulated due to the positive ROS imbalance [51] relative to the resting state.

\section{Role of Redox Cysteine in Platelets}

Free thiol groups and thiol-disulfide exchanges play central roles in the responses of platelets to stimuli [85]. For example, the reduction of a functional disulfide bond in the $\beta 3$ extracellular subunit of the $\alpha \mathrm{IIb} \beta 3$ receptor, which possesses a redox switch, via inside-out signaling induces conformational changes that enhance platelet activation [86]. PI-treated PCs, in particular UVB-treated platelets, have an increased affinity to the PAC- 1 antibody, suggesting that the $\alpha \mathrm{IIb} \beta 3$ receptor undergoes a conformational change into its active form [8]. In the same way, excessive exposure to UVC illumination disrupts the disulfide bond in $\alpha \mathrm{IIb} \beta 3$, thereby enhancing the affinity of the Arg-Gly-Asp (or RGD) motif for fibrinogen [87]. These studies suggest that UV light has a non-negligible impact on the redox system in platelets.

Free cysteine residues are the preferred targets for oxidation reactions, and they could be involved in sensing cellular oxidative stress, as part of a defense mechanism or in cellular regulation. Since the thiolate $\left(\mathrm{R}_{-} \mathrm{S}^{-}\right)$attacks the $\mathrm{H}_{2} \mathrm{O}_{2}$, the redox potential of protein-free thiols is influenced mainly by the chemical environment and can modulate $\mathrm{R}-\mathrm{SH} \mathrm{pK}$. The reactivity of protein-free thiols could depend on their accessibility and steric hindrance, since thiol oxidations are substitution nucleophile bi-molecular (SN2) reactions, implying a concerted backbone in the intermediate [88]. Accordingly, bulky groups surrounding an R-SH group will decrease its reactivity. Importantly, thiols are good oxygen acceptors and, among other oxidation states not listed here, can be reversibly transformed into R-S-S-R, R-SOH or R-SO ${ }_{2} \mathrm{H}$ or irreversibly transformed into $\mathrm{RSO}_{3} \mathrm{H}$ (Table 1). Here we only discuss reversible cysteine oxidation. Indeed, reversible cysteine oxidation is at the core of the second $\mathrm{H}_{2} \mathrm{O}_{2}$ messenger system and, to the best of our knowledge, has not been exhaustively studied in platelets. Posttranslational cysteine oxidation is reviewed elsewhere [89].

Table 1. Redox cysteine oxidation states.

\begin{tabular}{ccc}
\hline Name & Formulae & Oxidation State \\
\hline Cysteine & $\mathrm{R}-\mathrm{SH}$ & $-\mathrm{II}$ \\
Disulfide bridge & $\mathrm{R}-\mathrm{S}-\mathrm{S}-\mathrm{R}$ & $-\mathrm{I}$ \\
Glutathionylation & $\mathrm{R}-\mathrm{S}-\mathrm{S}-\mathrm{G}$ & $-\mathrm{I}$ \\
Sulfenic acid & $\mathrm{R}-\mathrm{SOH}$ & 0 \\
Sulfinic acid & $\mathrm{R}-\mathrm{SO}_{2} \mathrm{H}$ & $+\mathrm{II}$ \\
Sulfonic acid & $\mathrm{R}-\mathrm{SO}_{3} \mathrm{H}$ & $+\mathrm{IV}$ \\
\hline
\end{tabular}




\subsection{The Involvement of Cysteine in ROS Sensing and Defense}

Oxidative stress plays an active role in programmed cell death. Farah and Amberg hypothesized that the oxidation of cysteine residues in actin is a conserved cellular mechanism that senses oxidative stress and accelerates cell death [90]. This hypothesis was based on their study in yeast, where the oxidation of the highly conserved actin Cys-285 and Cys-374 residues impacts actin filaments (F-actin) polymerization and increases the ROS level. Fixation of the polymerization state of cytoskeletal actin is part of the apoptosis pathway. Actin assembly and disassembly are not only important in apoptosis; they are also related to changes in the shapes and the rapid spread of platelets during adhesion hemostasis (see Section 4.2).

The in vitro hypotonic shock response assay, which tests the capacity of platelets to recover their initial shape after hypotonic stimulation, showed different results for control platelets versus PI-treated platelets $[24,91,92]$. It would be interesting to verify the correlation between ROS imbalance and poorer cell shape recovery. Notably, PCs have a consistent plasma fraction that contains albumin, the most abundant plasma protein. Albumin is an important regulator of blood osmotic pressure, and it transports several substances, like hormones, in the blood. Albumin has also been proposed to act as an antioxidant, thanks to its high concentration and its ability to capture ROS with its free cysteine (Cys34). Carbalal et al. proposed sulfenylation of human serum albumin as a mechanism that could protect plasma free thiols via a mechanism in which ROS are stabilized by Cys34 before the formation of a disulfide bond [93]. This point of view considers $\mathrm{R}-\mathrm{SOH}$ to be an intermediate in the formation of the R-S-S-G moiety, protecting cysteine from further oxidation [89]. As a consequence, albumin could counter increases in ROS in PCs, thereby playing a protective role against platelet lesions.

In the cytosol, the DJ-1 protein (Parkinson disease protein 7 or PARK7) is suspected to be an oxidative stress sensor because of its highly conserved Cys106 residue, and it may help protect the mitochondrial membrane [43]. In our laboratory, we used 2D-GE to show a pI shift of the DJ-1 spot after INTERCEPT ${ }^{\mathrm{TM}}$ treatment, suggesting the presence of an oxidized form of the protein [43]. After this treatment, more than $20 \%$ of the DJ-1 protein was in its oxidized form in PCs [43].

Peroxiredoxin-2 (PrxII) has a similar protective effect against undesired platelet activation and thrombosis. Recently, the antioxidant behavior of PrxII was correlated with platelet activation by Jang's research group, who published a study on SHP-2 [94]. Indeed, PrxII downregulates GPVI-mediated platelet activation by efficiently trapping $\mathrm{H}_{2} \mathrm{O}_{2}$, thereby preventing SHP-2 sulfenylation and subsequent inactivation. PrxII antithrombotic activity was also validated in vivo using an arterial injury assay to investigate mice lacking the PRDXII gene [94].

\subsection{Cysteine-Mediated Redox Signaling}

Cells can exploit reversible thiol oxidation to transduce stimuli, for example via disulfide bonds and sulfenic acids. The difficulties in detecting the sulfenic acid moiety, $-\mathrm{SOH}$, is due mainly to its much lower $\mathrm{p} K_{\mathrm{a}}$ : it easily undergoes $\mathrm{RSO}^{-}$, which is a better nucleophile then thiolate $\mathrm{R}^{-} \mathrm{S}^{-}$, and this enhances its reactivity with other molecules [95]. This reversible and therefore transitory oxidation-based post-translational modification (oxPTM) is probably, like phosphorylation-based PTMs, part of a binary switch that modulates protein activity [96]. Oxidative disulfide formation is enhanced by $\mathrm{H}_{2} \mathrm{O}_{2}$ and can be involved in the formation of protein complexes or conformational changes that modulate protein function. Phosphotyrosine phosphatases are among the best understood examples of oxidative disulfide formation. In this case, a free cysteine thiol is reversibly converted to a sulfenic acid, inactivating the phosphatase function. It has been proposed that such oxPTMs are part of a widespread and highly conserved redox regulation mechanism that works in conjunction with receptor tyrosine kinases [97]. Inhibition of phosphotyrosine phosphatases enhances tyrosine phosphorylation (e.g., SHP2; see Section 3.3). There are other sulfenic acid-mediated mechanisms as well. In addition to oxidative folding, which occurs mainly in the endoplasmic reticulum, disulfide bond formation that is driven by R-SOH intermediates is involved in the assembly of protein complexes. One example is protein kinase $\mathrm{A}$, in which disulfide bond formation between regulatory subunits is 
driven by an $\mathrm{R}-\mathrm{SOH}$ intermediate and acts to induce the translocation of a protein complex from the cytosol to the cytoplasmic membrane [98].

Disulfide bonds should not only be considered entities that stabilize protein tertiary structure or that act as a defense mechanism. Indeed, Fiaschi et al. showed the importance of the formation of a mixed disulfide bond (i.e., the glutathionylation of actin Cys374) in enhancing the dynamic spread of murine fibroblasts and their adhesion via cytoskeletal rearrangement [99]. Their conclusion was based on the observation that glutathione depletion or the Cys-374-Ala substitution importantly affected actin fiber formation and fibroblast adhesion, further confirming their model based on the involvement of ROS production on integrin-mediated adhesion to extracellular matrix [100,101]. Thiol-disulfide exchanges also represent a redox switch in protein function [102]. The thiol oxidoreductase protein disulfide isomerase (PDI) is particularly interesting in the context of this review because it is secreted (inside T-granules) by platelets during activation [103]. Platelet PDI targets the extracellular domain of $\alpha \operatorname{Ilb} \beta 3$ and therefore mediates thrombus formation. Indeed, intravital microscopy demonstrated that the accumulation of PDI at the site of laser-induced arteriolar wall injury was markedly decreased in $\mathrm{B3}^{-/-}$mice [104]. Another mechanism by which PDI participates in thrombus formation involves the upregulation of NOX1 and NOX2, which increases ROS production [105].

Several PC proteins that are affected by PITs are mitochondrial proteins or proteins that are involved in preserving mitochondrial integrity [37]. The mitochondrial environment is the richest environment in the cell in terms of free cysteine thiols, and this contributes to mitochondrial characteristics and function [88]. Given the alkaline environment of the inner mitochondria due to protons being pumped into the intermembrane space, free cysteines are likely to be in the thiolate form. ROS are produced continuously along the oxidative phosphorylation chain. As a consequence, free thiols can easily be oxidized to $\mathrm{R}-\mathrm{SOH}$ or even to higher oxidation states (Table 1). In the mitochondrial matrix, as in other cell compartments, glutathione reacts with thiolates to protect protein function when there is an $\mathrm{H}_{2} \mathrm{O}_{2}$ imbalance.

\section{ROS-Phosphorylation Crosstalk}

Protein phosphorylation is one of the most important regulatory mechanisms in cell biology [106]. Among the reversible PTMs, phosphorylation is one of the most studied and best understood. The types and levels of kinases and phosphatases inside cells highlight the importance of phosphorylation as a regulatory mechanism. Furthermore, kinases and phosphatases are often in competition with respect to their target proteins, and many proteins and enzymes are regulated by phosphorylation at multiple sites. Protein phosphorylation is easily detected by Western blot analysis and by 2D-GE techniques [107]. Current mass spectrometry-based proteomic techniques permit the study of the phosphorylation level after phospho-peptide enrichment, allowing researchers to conduct untargeted experiments and thereby gain an overview of phosphorylation in cells $[108,109]$. In signal transduction, phosphorylation is often induced by first messengers, such as hormones and paracrine/autocrine agents, and it can act in a concerted way with second messengers like calcium ions, redox signaling molecules, nitric oxide and lipophilic molecules.

Interestingly, the link between UVB-ROS-phosphorylation and platelet activation was suggested by Van Marwijk Kooy et al. in 1993 [110]. They observed that after UVB illumination of platelets, there was increased fibrinogen binding that correlated with a $40 \%$ higher level of phosphorylation downstream of protein kinase C. UV-induced phosphorylation and platelet aggregation were significantly reduced in the presence of SOD and catalase, respectively, which are scavengers of $\mathrm{O}_{2}{ }^{-\cdot}$ and $\mathrm{H}_{2} \mathrm{O}_{2}$. They concluded that the ROS generated upon UVB exposure induces platelet activation-aggregation via protein kinase $\mathrm{C}$. Later, Schubert's group provided an important example of the impact of UVB-based PIT on the PTM proteome [111]. They used 1D gel semi-quantitative proteomics and phospho-immunoblotting and found that apheresis platelet bags resulted in enhanced phosphorylation of the vasodilator-stimulated phosphoprotein (VASP) after riboflavin-UVB treatment [111]. VASP is a highly concentrated cytosolic platelet protein involved in the ADP 
activation cascade, which promotes F-actin elongation. Its phosphorylation on Ser-157 and Ser-239 strongly correlates with $\alpha \operatorname{IIb} \beta 3$ binding to soluble fibrinogen and with platelet aggregation [112]. This observation led to the development of an in vitro assay that is currently in clinical use that tests the efficacy of antiplatelet treatments (such as clopidogrel, which binds to the P2Y12 receptor) on VASP phosphorylation [113]. This group investigated upstream kinase activity and showed that inhibiting p38MAPK after PIT treatment (Mirasol ${ }^{\circledR}$ in their study) significantly restored PC quality based on in vitro tests [114]. Indeed, the phosphorylation level was tested in treated versus untreated PCs, and the results showed that kinases had enhanced activity after exposure to UVB. In particular, p38MAPK showed a greater than two-fold increase in activity [114]. Finally, they demonstrated that the enhanced p38MAPK kinase activity induced by Mirasol ${ }^{\circledR}$ treatment triggered apoptosis in apheresis PCs [115]. Moreover, they also showed that Mirasol ${ }^{\circledR}$ treatment potentiates the phosphorylation of NF- $\kappa B$ and $I \kappa B \alpha$, enhancing redox-sensitive transcription activity [20]. In the context of this review, these findings suggest that the ROS produced during pathogen inactivation can interfere with protein phosphorylation and impact internal cell signaling.

The possible links between oxidative stress and cell signaling raise some fascinating possibilities. Recently, in human epidermoid carcinoma cells, Carroll's group demonstrated that endothelial growth factor receptor (EGFR) kinase activity is modulated by the oxidation of Cys979 into sulfenic acid after $\mathrm{H}_{2} \mathrm{O}_{2}$ reacts with its free thiol [116]. They optimized an experimental strategy for the site-specific analysis of protein -SOH that uses a sulfenic acid-specific probe (DYn-2) to fix this labile redox cysteine state. This allows sulfenylation to be studied in cells over time, and they specifically compared the basal sulfenylome with one in stressed conditions following $\mathrm{H}_{2} \mathrm{O}_{2}$ stimulation of $\mathrm{RKO}$ and A431 cells [117]. The identification of the sulfenic acid sites allowed the mechanistic study of activation-translocation of the transcription factor HIF1A by SIRT6. Our laboratory is currently using this strategy to characterize the platelet sulfenylome (Sonego, G.; Prudent, M.; et al., Mapping the platelet sulfenylome, Manuscript in writing process). Our aim is to assess the impact of PITs on PCs and to elucidate the connection between ROS second messengers that are produced during PC treatment and PC functionality in vitro.

\section{The Overlap of Redox Proteomics and Transfusion}

The storage conditions for PCs are continuously being changed and improved, with the result that different countries use different storage conditions. These changes also raise the issue of the cost-effectiveness of incremental improvements. Changes in storage conditions have suggested interesting new possibilities, and clinical trials must be continuously updated to reflect the changes. Moreover, improved clinical monitoring methods and the use of advanced analytical tests are being used to reassess abandoned practices for use in specific applications [118]. For example, whole blood storage, platelet cryopreservation and cold storage have been reconsidered for hemorrhagic shock treatment [119-121]. Cold storage at $4{ }^{\circ} \mathrm{C}$ has shown positive outcomes, and platelet function is conserved until day 15 in these conditions [119]. Therefore the field is evolving, and there is a danger that debate about the convenience of RT platelet storage could destabilize the paradigm. Along with other authors, Cap has criticized the RT storage, asserting that post-transfusion platelet recovery is not a universal criterion for platelet function and does not guarantee efficacy in the context of the targeted condition beyond prophylactic treatment [122]. While the debate over optimal PC storage conditions is not the focus of the present review, in terms of the advantages and disadvantages, costs, product availability, effectiveness, etc., we would like to make the point that "omic" research approaches can help clinicians and blood bankers make better medical decisions.

\subsection{The Impact of Antioxidants on PI-Treated PCS}

PITs are photochemical treatments or photo-treatments that induce oxidative lesions. Our lab has demonstrated the effects of PITs on oxidative processes in platelets by showing an important decrease in extracellular antioxidant power after INTERCEPT ${ }^{\circledR}$ treatment; the same effects were seen with our laboratory's in-house riboflavin/UVB system [24]. Antioxidant power was measured electrochemically 
using EDEL technology (in arbitrary units equivalent to one micromolar ascorbic acid) by deposing a $2 \mu \mathrm{L}$ drop of liquid sample on a microchip. [123,124]. Using the results, our group developed a quality control assay to assess the effects of PIT before product delivery [123]. One solution for countering the oxidative damage of PITs that has been proposed in the literature is to supplement PCs with antioxidants. A few studies have tested the ability of added antioxidants to decrease the carbonylation level during platelet storage/aging and to reduce oxidative stress $[125,126]$. The idea is that antioxidants will directly scavenge ROS and protect cellular components like glutathione. However, this supplementation is questionable and would have to be fine-tuned as antioxidants clearly modulate platelet function.

Olas and Wachowitz studied the effect of resveratrol and vitamin $C$ on the inhibition of ROS production [127]. Vitamin C concentrations of 0.75 to $3 \mathrm{mM}$ showed good effectiveness against ROS, while resveratrol only partially inhibited ROS production. Sobotkova et al. showed the antioxidant properties of resveratrol on washed platelets using trolox, a hydrophilic analog of vitamin E, using an equivalent antioxidant capacity assay and indirect measurements of $\mathrm{OH}$. following salicylic acid hydroxylation into 2,3-DHB and 2,5-DHB [128]. Importantly, resveratrol, which is naturally found in wine, seems to modulate key proteins involved in intracellular signaling, including effects on protein kinase activation (p38MAPK), phospholipase $\mathrm{C}$, the $\mathrm{Ca}^{2+}$ cascade and the activation of $\mathrm{NO} /$ cyclic GMP [129]. However, due to suggested differences in redox-sensitive pathways, the inhibition of platelet activation by antioxidants remains limited by their specific properties [57]. ROS production that is induced by PIT may be randomly distributed inside the cell or it may be concentrated in the vicinity of DNA and RNA molecules, especially in the case of amotosalen, which is an intercalation compound with chemical activity that differs from riboflavin. In addition, there is a risk that the use of antioxidants during the PI process will decrease the PI efficacy by quenching the effect of the treatment. Lastly, antioxidants such as vitamin $\mathrm{E}$ and $\beta$-carotene inhibit the primary function of platelets and are suspected of being associated with hemorrhagic stroke in male patients with lung cancer [130]. Antioxidants that protect supernatant proteins and the integrity of platelet membranes probably have the best chance of success.

\subsection{Cold Storage and Cryopreservation}

There are several possible strategies for reducing or eliminating the risk of bacterial growth during RT storage while avoiding the use of PITs and without shortening storage time. Cold storage and cryopreservation are among the possible solutions. Cold storage has not been in general use since the 1970s. Despite shortened recirculation issues, recent clinical studies have shown that cold-stored products have potential for use for specific treatments [131]. Cryopreserved platelets have an obvious advantage in terms of overcoming the issue of short shelf life. Recently, autologous cryopreserved platelets were successfully transfused into HLA-alloimmunized patients, showing good conservation of their function in the presence of strong agonists [132]. However, relative to storage at RT, low temperature storage (both at 4 and $-80{ }^{\circ} \mathrm{C}$ ) results in platelet hyperactivity. In cryopreserved platelets, it has been hypothesized that the development of a pro-coagulant phenotype at the membrane underlies the altered in vivo hemostatic activity [133]. Moreover, the activation of cryopreserved platelets seems to occur via exposure of $P$-selectin at the platelet and microparticle membranes [120]. Measurement of dynamic light scattering (DLS) scores using the ThromboLUX ${ }^{\mathrm{TM}}$ system showed significant differences in particle composition between RT-stored platelets and cold-stored or cryopreserved platelets, suggesting increased microparticulation in response to storage at low temperature [121].

Redox regulation of platelet microparticulation is still poorly understood, but elevated levels of microparticles are associated with inflammatory diseases, such as arterial thrombosis, diabetes, rheumatoid arthritis and ischemic events $[134,135]$. Holbrook et al. showed that thrombin stimulation of platelets induces the shedding of microparticles containing PDI and ERp57, both of which are disulfide isomerases [136]. We mentioned above that the PDI on the platelet surface can regulate the 
cysteine-rich $\beta 3$ region of the $\alpha \operatorname{Ilb} \beta 3$ integrin as well as the affinity of $\alpha \operatorname{Ilb} \beta 3$ for fibrinogen. Essex and Li significantly downregulated the affinity of $\alpha \mathrm{IIb} \beta 3$ for PAC-1, specifically by inhibiting PDI activity with rabbit anti-PDI IgG [137]. Therefore, cold stored and cryopreserved platelets most likely show hyperactivation relative to RT-stored platelets due to increased microparticulation [120]. Nevertheless, PDI is not the only disulfide isomerase to act at the platelet surface. Holbrook and coworkers identified several new disulfide isomerases on the platelet surface using immunoblotting [136]. Confirming intense oxidoreductase activity at the platelet membrane, PDI was found to be released by platelets during injury as an activator of the tissue factor that initiates fibrin polymerization after thrombin activation [138]. Indeed, PDI catalyzes the formation of an intra-disulfide bond between a mixed disulfide (i.e., GSSR) and a free thiol on the tissue factor. Moreover, low temperature storage seems to affect redox regulation by enhancing the capacity of platelets to synthetize $\mathrm{TxA}_{2}$ via $\mathrm{AA}$ stimulation [139]. In spite of these differences relative to PI-treated platelets, a number of clinical studies have been conducted using platelets that were stored at low temperatures, and they were shown to be safe and thus to represent a real option for patients.

\subsection{Whole Blood Inactivation and Cold Storage}

Pathogen inactivation to prevent transfusion-transmitted infections has become a central paradigm in transfusion medicine. While several countries have adopted regulations for PIT use in PC manufacturing, others still need to upgrade their blood supply systems. PITs have been used during infection crises, for example in the Chikungunya outbreak on Reunion Island, to avoid the collapse of the blood component supply [140]. Therefore, PITs are currently part of the arsenal used to fight emerging pathogens. Unfortunately, UVA-based PITs cannot be used to inactivate red blood cell (RBC) concentrates or even whole blood. Due to the overlapping absorption spectra of hemoglobin and its high concentration in blood, technologies that employ UVA radiation damage RBCs, increasing the risk of an immune response in the recipient [141]. To overcome this barrier to use, a chemical-based S-303 inactivating system has been developed that uses glutathione combined with the amphipathic chemical compound S-303 [142]. The membrane-permeable compound comprises a linker that can covalently bind to RNA/DNA, blocking their replication, plus an inert tail reporter released upon the binding of nucleotides. Glutathione molecules, which are not membrane permeable, quench the S-303 side reactions, protecting proteins and other extracellular components. This system avoids the use of photochemistry to inactivate pathogens. The first evidence that S-303 can be used to treat whole blood was presented by Mufti et al. [143]. Treatment of whole blood could simplify the pathogen inactivation process, allowing the treated blood to subsequently be used to obtain plasma, platelets and RBC components via the buffy coat method. However, S-303-based inactivation does have an impact on cells. Indeed, erythrocyte concentrates showed decreased glycolysis and increased extracellular potassium levels after treatment with S-303 [143]. Due to its affordability and potential for widespread use, the idea of treating whole blood has also been tested using the Mirasol ${ }^{\circledR}$ system. To assess the suitability of the UVB/riboflavin treatment for whole blood, the viability of the different components was tested in vitro. Schubert et al. found significant deterioration in plasma coagulation factor activation and increased RBC aging in components derived from whole blood that was PI-treated [144]. Interestingly, platelets showed fewer lesions than PI-treated PCs. Again, further studies are needed to clarify the effects of this system on specific molecular components.

As a final remark, it is important to notice that all developments and innovations in transfusion medicine must be based not only on scientific data but also on safety and economic issues.

\section{Conclusions}

In platelets, the ROS balance controls both platelet activation and the platelet aggregation process. In the context of transfusion medicine, PITs slightly disturb the resting state of platelets. The clinical impact of this disturbance is not completely understood, although the safety of PITs has been shown. However, in vitro tests show evidence of lesions in treated PCs. Considering the increase in the protein 
carbonylation level in PI-treated PCs, it is reasonable to suspect that these lesions activate platelets via ROS. ROS are very reactive small molecules that can transduce stimuli into biological responses. Although the link between second messenger ROS and platelet activation is now well known, the molecular mechanisms that regulate this process remain to be elucidated. As described here, the redox potential of cysteine plays a central role in signal transduction. Accordingly, PITs that produce oxidative stress could drive the creation of PCs that contain platelets that are slightly hyperactive, show increased lesions with increased storage time, and may not be well suited to the characteristics of the recipient. Alternative storage conditions could be suited to other clinical status; we must more fully understand the in vitro functionality of platelets to fully understand the clinical implications of PITs.

Advanced proteomics, and in particular redox proteomics, are of primary importance for deciphering the defined steps in the platelet activation and aggregation processes. As highlighted here, the identification of platelet sulfenylation sites, among other oxPTM sites, will help researchers select candidate proteins that are sensitive to ROS and help to better characterize the final labile blood product. The discovery of these oxidative mechanisms could go beyond concerns about transfusion and give us a better understanding of inflammatory diseases that are accompanied by platelet hyperactivity [127].

Finally, from the viewpoint of blood centers, further basic and "omic" research that investigates redox regulations, as reviewed here, will be helpful for developing innovative and improved strategies for preparing and storing platelets. Although this work is promising, the relationships between platelet biochemistry and clinical effects must be elucidated further, and redox proteomics studies of PCs should ideally be accompanied by functional tests. Moreover, it is important to question the value and potential of current PITs and to think about the possibility of novel inactivation systems that do not rely on oxidative stress, such as whole blood inactivation, which does not use UV light.

Acknowledgments: This work was supported by a grant of the research committee of Transfusion SRC Switzerland.

Author Contributions: Giona Sonego, Michel Prudent and Mélanie Abonnenc wrote the manuscript; Jean-Daniel Tissot and Niels Lion revised the overall manuscript. All the authors approved the final version.

Conflicts of Interest: Niels Lion received a conference honorarium on two occasions from Cerus, the provider of the INTERCEPT Blood System. Jean-Daniel Tissot received an honorarium from TerumoBCT (European customer panel). The other authors have disclosed no conflict of interest.

$\begin{array}{ll}\text { Abbreviations } \\ \text { 2D-GE } & \text { Two dimensional-gel electrophoresis } \\ \text { F-actin } & \text { Actin filaments } \\ \text { AA } & \text { Ascorbic acid } \\ \text { CCI } & \text { Corrected count increment } \\ \text { COX1 } & \text { Cyclooxygenase 1 } \\ \text { CyPA } & \text { Cyclophilin A } \\ \text { DCF } & 2^{\prime}, 7^{\prime} \text {-dichlorofluorescein } \\ \text { F2-IsoP } & \text { F2 isoprostane } \\ \text { GP-Ib-IX } & \text { Glycoprotein Ib-IX } \\ \text { GPVI } & \text { Glycoprotein VI } \\ \text { H } 2 \text { DCFDA } & 2^{\prime}, 7^{\prime} \text {-dichlorodihydrofluorescein diacetate } \\ \text { IP3 } & \text { Isoprostane } 3 \\ \text { LAT } & \text { Linker of activated T-cells } \\ \text { mPT } & \text { Mitochondria permeability transition } \\ \text { NOX } & \text { NADPH oxidase } \\ \text { PC } & \text { Platelet concentrate } \\ \text { PDI } & \text { Protein disulfide isomerase } \\ \text { PGG2 } & \text { Prostaglandin G2 } \\ \text { PI } & \text { Pathogen inactivation } \\ \text { PIT } & \text { Pathogen inactivation technology } \\ \text { PLA } 2 & \text { Phospholipase A2 }\end{array}$




$\begin{array}{ll}\text { PLCg-2 } & \text { Phospholipase Cg } 2 \\ \text { PrxII } & \text { Peroxiredoxin-II } \\ \text { PTM } & \text { Post-translational modification } \\ \text { oxPTM } & \text { Oxidative PTM } \\ \text { RBC } & \text { Red blood cell } \\ \text { ROS } & \text { Reactive oxygen species } \\ \text { RT } & \text { Room temperature } \\ \text { SOD } & \text { Superoxide dismutase } \\ \text { TRAF4 } & \text { TNF receptor associated factor 4 } \\ \text { TXA2 } & \text { Thromboxane A2 }\end{array}$

\section{References}

1. Garraud, O. Editorial: Platelets as immune cells in physiology and immunopathology. Front. Immunol. 2015, 6, 274. [CrossRef] [PubMed]

2. Rondina, M.T.; Weyrich, A.S.; Zimmerman, G.A. Platelets as cellular effectors of inflammation in vascular diseases. Circ. Res. 2013, 112, 1506-1519. [CrossRef] [PubMed]

3. Holbro, A.; Infanti, L.; Sigle, J.; Buser, A. Platelet transfusion: Basic aspects. Swiss Med. Wkly. 2013, 143, 13885. [CrossRef] [PubMed]

4. Hoffmeister, K.M.; Felbinger, T.W.; Falet, H.; Denis, C.V.; Bergmeier, W.; Mayadas, T.N.; von Andrian, U.H.; Wagner, D.D.; Stossel, T.P.; Hartwig, J.H. The clearance mechanism of chilled blood platelets. Cell 2003, 112, 87-97. [CrossRef]

5. Salunkhe, V.; van der Meer, P.F.; de Korte, D.; Seghatchian, J.; Gutiérrez, L. Development of blood transfusion product pathogen reduction treatments: A review of methods, current applications and demands. Transfus. Apher. Sci. 2015, 52, 19-34. [CrossRef] [PubMed]

6. Kaiser-Guignard, J.; Canellini, G.; Lion, N.; Abonnenc, M.; Osselaer, J.-C.; Tissot, J.-D. The clinical and biological impact of new pathogen inactivation technologies on platelet concentrates. Blood Rev. 2014, 28, 235-241. [CrossRef] [PubMed]

7. Prowse, C.V. Component pathogen inactivation: A critical review. Vox Sang. 2013, 104, 183-199. [CrossRef] [PubMed]

8. Abonnenc, M.; Sonego, G.; Kaiser-Guignard, J.; Crettaz, D.; Prudent, M.; Tissot, J.-D.; Lion, N. In vitro evaluation of pathogen-inactivated buffy coat-derived platelet concentrates during storage: Psoralen-based photochemical treatment step-by-step. Blood Transfus. 2015, 13, 255-264. [PubMed]

9. Ignatova, A.A.; Karpova, O.V.; Trakhtman, P.E.; Rumiantsev, S.A.; Panteleev, M.A. Functional characteristics and clinical effectiveness of platelet concentrates treated with riboflavin and ultraviolet light in plasma and in platelet additive solution. Vox Sang. 2016, 110, 244-252. [CrossRef] [PubMed]

10. Janetzko, K.; Hinz, K.; Marschner, S.; Goodrich, R.; Kluter, H. Evaluation of different preparation procedures of pathogen reduction technology mirasol(R)-treated platelets collected by plateletpheresis. Transfus. Med. Hemother. 2009, 36, 309-315. [CrossRef] [PubMed]

11. Maurer-Spurej, E.; Larsen, R.; Labrie, A.; Heaton, A.; Chipperfield, K. Microparticle content of platelet concentrates is predicted by donor microparticles and is altered by production methods and stress. Transfus. Apher. Sci. 2016, 55, 35-43. [CrossRef] [PubMed]

12. Kerkhoffs, J.L.H. Evaluation of platelet transfusion clinical trials-Response to Corash \& Sherman. Br. J. Haematol. 2011, 153, 531-532.

13. Kerkhoffs, J.L.H.; van Putten, W.L.J.; Novotny, V.M.J.; Boekhorst, P.; Schipperus, M.R.; Zwaginga, J.J.; van Pampus, L.C.M.; de Greef, G.E.; Luten, M.; Huijgens, P.C.; et al. Clinical effectiveness of leucoreduced, pooled donor platelet concentrates, stored in plasma or additive solution with and without pathogen reduction. Br. J. Haematol. 2010, 150, 209-217. [CrossRef] [PubMed]

14. Corash, L.; Sherman, C.D. Evaluation of platelet transfusion clinical trials. Br. J. Haematol. 2011, 153, 529-531. [CrossRef] [PubMed]

15. Cazenave, J.P.; Follea, G.; Bardiaux, L.; Boiron, J.M.; Lafeuillade, B.; Debost, M.; Lioure, B.; Harousseau, J.L.; Tabrizi, R.; Cahn, J.Y.; et al. A randomized controlled clinical trial evaluating the performance and safety of platelets treated with MIRASOL pathogen reduction technology. Transfusion 2010, 50, 2362-2375. [CrossRef] [PubMed] 
16. Lozano, M.; Knutson, F.; Tardivel, R.; Cid, J.; Maymo, R.M.; Lof, H.; Roddie, H.; Pelly, J.; Docherty, A.; Sherman, C.; et al. A multi-centre study of therapeutic efficacy and safety of platelet components treated with amotosalen and ultraviolet A pathogen inactivation stored for 6 or $7 \mathrm{~d}$ prior to transfusion. Br. J. Haematol. 2011, 153, 393-401. [CrossRef] [PubMed]

17. Heddle, N.M.; Ness, P.M. Consort and clinical trial reporting: Room for improvement. Transfusion 2016, 56, 781-783. [CrossRef] [PubMed]

18. Cook, R.J.; Heddle, N.M. Clinical trials evaluating pathogen-reduced platelet products: Methodologic issues and recommendations. Transfusion 2013, 53, 1843-1855. [CrossRef] [PubMed]

19. Feys, H.B.; van Aelst, B.; Devreese, K.; Devloo, R.; Coene, J.; Vandekerckhove, P.; Compernolle, V. Oxygen removal during pathogen inactivation with riboflavin and UV light preserves protein function in plasma for transfusion. Vox Sang. 2014, 106, 307-315. [CrossRef] [PubMed]

20. Johnson, L.; Marks, D. Treatment of platelet concentrates with the mirasol pathogen inactivation system modulates platelet oxidative stress and NF-kB activation. Transfus. Med. Hemother. 2015, 42, 167-173. [CrossRef] [PubMed]

21. Kitamura, N.; Kohtani, S.; Nakagaki, R. Molecular aspects of furocoumarin reactions: Photophysics, photochemistry, photobiology, and structural analysis. J. Photochem. Photobiol. C Photochem. Rev. 2005, 6, 168-185. [CrossRef]

22. Cardoso, D.R.; Libardi, S.H.; Skibsted, L.H. Riboflavin as a photosensitizer. Effects on human health and food quality. Food Funct. 2012, 3, 487-502. [CrossRef] [PubMed]

23. Herrling, T.; Jung, K.; Fuchs, J. Measurements of UV-generated free radicals/reactive oxygen species (ROS) in skin. Spectrochim. Acta A Mol. Biomol. Spectrosc. 2006, 63, 840-845. [CrossRef] [PubMed]

24. Abonnenc, M.; Sonego, G.; Crettaz, D.; Aliotta, A.; Prudent, M.; Tissot, J.-D.; Lion, N. In vitro study of platelet function confirms the contribution of the ultraviolet $\mathrm{B}$ (UVB) radiation in the lesions observed in riboflavin/UVB-treated platelet concentrates. Transfusion 2015, 55, 2219-2230. [CrossRef] [PubMed]

25. Freedman, J.E. Oxidative stress and platelets. Arterioscler. Thromb. Vasc. Biol. 2008, 28, s11-s16. [CrossRef] [PubMed]

26. Zhang, B.; Zehnder, J.L. Oxidative stress and immune thrombocytopenia. Consult. Hematol. 2013, 50, e1-e4. [CrossRef] [PubMed]

27. Kim, J.H.; Bae, H.Y.; Kim, S.Y. Clinical marker of platelet hyperreactivity in diabetes mellitus. Diabetes Metab. J. 2013, 37, 423-428. [CrossRef] [PubMed]

28. Pignatelli, P.; Pulcinelli, F.M.; Lenti, L.; Gazzaniga, P.P.; Violi, F. Hydrogen peroxide is involved in collagen-induced platelet activation. Blood 1998, 91, 484-490. [PubMed]

29. Chakrabarti, A.; Halder, S.; Karmakar, S. Erythrocyte and platelet proteomics in hematological disorders. Proteomics Clin. Appl. 2016, 10, 403-414. [CrossRef] [PubMed]

30. Circu, M.L.; Aw, T.Y. Reactive oxygen species, cellular redox systems and apoptosis. Free Radic. Biol. Med. 2010, 48, 749-762. [CrossRef] [PubMed]

31. Begonja, A.J.; Gambaryan, S.; Geiger, J.; Aktas, B.; Pozgajova, M.; Nieswandt, B.; Walter, U. Platelet $\mathrm{NAD}(\mathrm{P}) \mathrm{H}$-oxidase-generated ROS production regulates $\alpha \mathrm{IIb} \beta 3$-integrin activation independent of the NO/cGMP pathway. Blood 2005, 106, 2757-2760. [CrossRef] [PubMed]

32. Krötz, F.; Sohn, H.Y.; Gloe, T.; Zahler, S.; Riexinger, T.; Schiele, T.M.; Becker, B.F.; Theisen, K.; Klauss, V.; Pohl, U. NAD $(\mathrm{P}) \mathrm{H}$ oxidase-dependent platelet superoxide anion release increases platelet recruitment. Blood 2002, 100, 917. [CrossRef] [PubMed]

33. Go, Y.-M.; Jones, D.P. The redox proteome. J. Biol. Chem. 2013, 288, 26512-26520. [CrossRef] [PubMed]

34. Singh, H.; Chaudhary, R.; Ray, V. Evaluation of platelet storage lesions in platelet concentrates stored for seven days. Indian J. Med. Res. 2003, 118, 243-246. [PubMed]

35. Thiele, T.; Iuga, C.; Janetzky, S.; Schwertz, H.; Gesell Salazar, M.; Furll, B.; Volker, U.; Greinacher, A.; Steil, L. Early storage lesions in apheresis platelets are induced by the activation of the integrin $\alpha \operatorname{Ilb} \beta(3)$ and focal adhesion signaling pathways. J. Proteom. 2012, 76, 297-315. [CrossRef] [PubMed]

36. Schubert, P.; Devine, D.V. Towards targeting platelet storage lesion-related signaling pathways. Blood Transfus. 2010, 8, 69-72.

37. Prudent, M.; D'Alessandro, A.; Cazenave, J.P.; Devine, D.V.; Gachet, C.; Greinacher, A.; Lion, N.; Schubert, P.; Steil, L.; Thiele, T.; et al. Proteome changes in platelets after pathogen inactivation-An interlaboratory consensus. Transfus. Med. Rev. 2014, 28, 72-83. [CrossRef] [PubMed] 
38. Schubert, P.; Culibrk, B.; Karwal, S.; Goodrich, R.P.; Devine, D.V. Protein translation occurs in platelet concentrates despite riboflavin/UV light pathogen inactivation treatment. Proteomics Clin. Appl. 2016, 10, 839-850. [CrossRef] [PubMed]

39. Harrison, P.; Briggs, C. Chapter 27-Platelet Counting. In Platelets, 3rd ed.; Michelson, A.D., Ed.; Elsevier: London, UK, 2013; pp. 547-557.

40. Landry, P.; Plante, I.; Ouellet, D.L.; Perron, M.P.; Rousseau, G.; Provost, P. Existence of a microRNA pathway in anucleate platelets. Nat. Struct. Mol. Biol. 2009, 16, 961-966. [CrossRef] [PubMed]

41. Burkhart, J.M.; Vaudel, M.; Gambaryan, S.; Radau, S.; Walter, U.; Martens, L.; Geiger, J.; Sickmann, A.; Zahedi, R.P. The first comprehensive and quantitative analysis of human platelet protein composition allows the comparative analysis of structural and functional pathways. Blood 2012, 120, e73. [CrossRef] [PubMed]

42. Marrocco, C.; D'Alessandro, A.; Girelli, G.; Zolla, L. Proteomic analysis of platelets treated with $\gamma$ irradiation versus a commercial photochemical pathogen reduction technology. Transfusion 2013, 53, 1808-1820. [CrossRef] [PubMed]

43. Prudent, M.; Crettaz, D.; Delobel, J.; Tissot, J.-D.; Lion, N. Proteomic analysis of Intercept-treated platelets. J. Proteom. 2012, 76, 316-328. [CrossRef] [PubMed]

44. Hechler, B.; Ohlmann, P.; Chafey, P.; Ravanat, C.; Eckly, A.; Maurer, E.; Mangin, P.; Isola, H.; Cazenave, J.P.; Gachet, C. Preserved functional and biochemical characteristics of platelet components prepared with amotosalen and ultraviolet A for pathogen inactivation. Transfusion 2013, 53, 1187-1200. [CrossRef] [PubMed]

45. Thiele, T.; Sablewski, A.; Iuga, C.; Bakchoul, T.; Bente, A.; Gorg, S.; Volker, U.; Greinacher, A.; Steil, L. Profiling alterations in platelets induced by amotosalen/UVA pathogen reduction and $\gamma$ irradiation-A LC-ESI-MS/MS-based proteomics approach. Blood Transfus. 2012, 10, 63-70.

46. Madian, A.G.; Regnier, F.E. Detection of oxidized polypeptides. U.S. Patent 9,134,318, 15 September 2015.

47. Suzuki, Y.J.; Carini, M.; Butterfield, D.A. Protein carbonylation. Antioxid. Redox Signal. 2010, 12, 323-325. [CrossRef] [PubMed]

48. Prudent, M.; Sonego, G.; Abonnenc, M.; Tissot, J.-D.; Lion, N. LC-MS/MS Analysis and comparison of oxidative damages on peptides induced by pathogen reduction technologies for platelets. J. Am. Soc. Mass Spectrom. 2014, 25, 651-661. [CrossRef] [PubMed]

49. Cattaruzza, M.; Hecker, M. Protein carbonylation and decarboylation: A new twist to the complex response of vascular cells to oxidative stress. Circ. Res. 2008, 102, 273-274. [CrossRef] [PubMed]

50. Wright, A.; Bubb, W.A.; Hawkins, C.L.; Davies, M.J. Singlet oxygen-mediated protein oxidation: Evidence for the formation of reactive side chain peroxides on tyrosine residues. Photochem. Photobiol. 2002, 76, 35-46. [CrossRef]

51. Abonnenc, M.; Crettaz, D.; Marvin, L.; Grund, B.; Sonego, G.; Bardyn, M.; Tissot, J.-D.; Prudent, M.; Rochat, B.; Lion, N. Metabolomic profiling highlights oxidative damages in platelet concentrates treated for pathogen inactivation and shows protective role of urate. Metabolomics 2016, 12, 188. [CrossRef]

52. Dalle-Donne, I.; Aldini, G.; Carini, M.; Colombo, R.; Rossi, R.; Milzani, A. Protein carbonylation, cellular dysfunction, and disease progression. J. Cell. Mol. Med. 2006, 10, 389-406. [CrossRef] [PubMed]

53. Reid, S.; Johnson, L.; Woodland, N.; Marks, D.C. Pathogen reduction treatment of buffy coat platelet concentrates in additive solution induces proapoptotic signaling. Transfusion 2012, 52, 2094-2103. [CrossRef] [PubMed]

54. Wong, C.M.; Cheema, A.K.; Zhang, L.; Suzuki, Y.J. Protein carbonylation as a novel mechanism in redox signaling. Circ. Res. 2008, 102, 310-318. [CrossRef] [PubMed]

55. Májek, P.; Reicheltová, Z.; Štikarová, J.; Suttnar, J.; Sobotková, A.; Dyr, J.E. Proteome changes in platelets activated by arachidonic acid, collagen, and thrombin. Proteome Sci. 2010, 8, 1-13.

56. Alexandru, N.; Constantin, A.; Popov, D. Carbonylation of platelet proteins occurs as consequence of oxidative stress and thrombin activation, and is stimulated by ageing and type 2 diabetes. Clin. Chem. Lab. Med. 2008, 46, 528-536. [CrossRef] [PubMed]

57. Bakdash, N.; Williams, M.S. Spatially distinct production of reactive oxygen species regulates platelet activation. Free Radic. Biol. Med. 2008, 45, 158-166. [CrossRef] [PubMed]

58. Carrim, N.; Arthur, J.F.; Hamilton, J.R.; Gardiner, E.E.; Andrews, R.K.; Moran, N.; Berndt, M.C.; Metharom, P. Thrombin-induced reactive oxygen species generation in platelets: A novel role for protease-activated receptor 4 and GPIb $\alpha$. Redox Biol. 2015, 6, 640-647. [CrossRef] [PubMed] 
59. Carrim, N.; Walsh, T.G.; Consonni, A.; Torti, M.; Berndt, M.C.; Metharom, P. Role of focal adhesion tyrosine kinases in GPVI-dependent platelet activation and reactive oxygen species formation. PLoS ONE 2014, 9, e113679. [CrossRef] [PubMed]

60. Wang, L.; Soe, N.N.; Sowden, M.; Xu, Y.; Modjeski, K.; Baskaran, P.; Kim, Y.; Smolock, E.M.; Morrell, C.N.; Berk, B.C. Cyclophilin A is an important mediator of platelet function by regulating integrin $\alpha \mathrm{IIb} \beta 3$ bidirectional signalling. Thromb. Haemost. 2014, 111, 873-882. [CrossRef] [PubMed]

61. Soe, N.N.; Sowden, M.; Baskaran, P.; Smolock, E.M.; Kim, Y.; Nigro, P.; Berk, B.C. Cyclophilin A is required for angiotensin II-induced $\mathrm{p} 47^{\mathrm{phox}}$ translocation to caveolae in vascular smooth muscle cells. Arterioscler. Thromb. Vasc. Biol. 2013, 33, 2147-2153. [CrossRef] [PubMed]

62. Caccese, D.; Praticò, D.; Ghiselli, A.; Natoli, S.; Pignatelli, P.; Sanguigni, V.; Iuliano, L.; Violi, F. Superoxide anion and hydroxyl radical release by collagen-induced platelet aggregation-Role of arachidonic acid metabolism. Thromb. Haemost. 2000, 83, 485-490. [PubMed]

63. Arthur, J.F.; Gardiner, E.E.; Kenny, D.; Andrews, R.K.; Berndt, M.C. Platelet receptor redox regulation. Platelets 2008, 19, 1-8. [CrossRef] [PubMed]

64. Arthur, J.F.; Shen, Y.; Gardiner, E.E.; Coleman, L.; Murphy, D.; Kenny, D.; Andrews, R.K.; Berndt, M.C. TNF receptor-associated factor 4 (TRAF4) is a novel binding partner of glycoprotein Ib and glycoprotein VI in human platelets. J. Thromb. Haemost. 2011, 9, 163-172. [CrossRef] [PubMed]

65. Arthur, J.F.; Qiao, J.; Shen, Y.; Davis, A.K.; Dunne, E.; Berndt, M.C.; Gardiner, E.E.; Andrews, R.K. ITAM receptor-mediated generation of reactive oxygen species in human platelets occurs via Syk-dependent and Syk-independent pathways. J. Thromb. Haemost. 2012, 10, 1133-1141. [CrossRef] [PubMed]

66. Korbecki, J.; Baranowska-Bosiacka, I.; Gutowska, I.; Chlubek, D. The effect of reactive oxygen species on the synthesis of prostanoids from arachidonic acid. J. Physiol. Pharmacol. 2013, 64, 409-421. [PubMed]

67. Morel, A.; Miller, E.; Bijak, M.; Saluk, J. The increased level of COX-dependent arachidonic acid metabolism in blood platelets from secondary progressive multiple sclerosis patients. Mol. Cell. Biochem. 2016, 420, 85-94. [CrossRef] [PubMed]

68. Lambeth, J.D. NOX enzymes and the biology of reactive oxygen. Nat. Rev. Immunol. 2004, 4, 181-189. [CrossRef] [PubMed]

69. Violi, F.; Pignatelli, P. Platelet NOX, a novel target for anti-thrombotic treatment. Thromb. Haemost. 2014, 111, 817-823. [CrossRef] [PubMed]

70. Bedard, K.; Krause, K.-H. The NOX Family of ROS-generating NADPH oxidases: Physiology and pathophysiology. Physiol. Rev. 2007, 87, 245-313. [CrossRef] [PubMed]

71. Jiang, F.; Zhang, Y.; Dusting, G.J. NADPH oxidase-mediated redox signaling: roles in cellular stress response, stress tolerance, and tissue repair. Pharmacol. Rev. 2011, 63, 218-242. [CrossRef] [PubMed]

72. Finazzi-Agrò, A.; Menichelli, A.; Persiani, M.; Biancini, G.; del Principe, D. Hydrogen peroxide release from human blood platelets. Biochim. Biophys. Acta 1982, 718, 21-25. [CrossRef]

73. Delaney, M.K.; Kim, K.; Estevez, B.; Xu, Z.; Stojanovic-Terpo, A.; Shen, B.; Ushio-Fukai, M.; Cho, J.; Du, X. Differential roles of the NADPH-oxidase 1 and 2 in platelet activation and thrombosis. Arterioscler. Thromb. Vasc. Biol. 2016, 36, 846-854. [CrossRef] [PubMed]

74. Walsh, T.G.; Berndt, M.C.; Carrim, N.; Cowman, J.; Kenny, D.; Metharom, P. The role of NOX1 and NOX2 in GPVI-dependent platelet activation and thrombus formation. Redox Biol. 2014, 2, 178-186. [CrossRef] [PubMed]

75. Pignatelli, P.; Carnevale, R.; Di Santo, S.; Bartimoccia, S.; Sanguigni, V.; Lenti, L.; Finocchi, A.; Mendolicchio, L.; Soresina, A.R.; Plebani, A.; et al. Inherited human gp91 ${ }^{\text {phox }}$ deficiency is associated with impaired isoprostane formation and platelet dysfunction. Arterioscler. Thromb. Vasc. Biol. 2011, 31, 423-434. [CrossRef] [PubMed]

76. Iuliano, L.; Praticò, D.; Ghiselli, A.; Bonavita, M.S.; Violi, F. Superoxide dismutase triggers activation of "primed" platelets. Arch. Biochem. Biophys. 1991, 289, 180-183. [CrossRef]

77. Yun, S.-H.; Sim, E.-H.; Goh, R.-Y.; Park, J.-I.; Han, J.-Y. Platelet activation: The mechanisms and potential biomarkers. BioMed Res. Int. 2016, 2016, 9060143. [CrossRef] [PubMed]

78. Sangkuhl, K.; Shuldiner, A.R.; Klein, T.E.; Altman, R.B. Platelet aggregation pathway. Pharmacogenet. Genom. 2011, 21, 516-521. [CrossRef] [PubMed]

79. Dayal, S.; Wilson, K.M.; Motto, D.G.; Miller, F.J.; Chauhan, A.K.; Lentz, S.R. Hydrogen peroxide promotes aging-related platelet hyperactivation and thrombosis. Circulation 2013, 127, 1308-1316. [CrossRef] [PubMed] 
80. Jang, J.Y.; Min, J.H.; Chae, Y.H.; Baek, J.Y.; Wang, S.B.; Park, S.J.; Oh, G.T.; Lee, S.-H.; Ho, Y.-S.; Chang, T.-S. Reactive oxygen species play a critical role in collagen-induced platelet activation via SHP-2 oxidation. Antioxid. Redox Signal. 2014, 20, 2528-2540. [CrossRef] [PubMed]

81. Zhang, P.; Du, J.; Zhao, L.; Wang, X.; Zhang, Y.; Yan, R.; Dai, J.; Liu, G.; Zhang, F.; Dai, K. The role of intraplatelet reactive oxygen species in the regulation of platelet glycoprotein Ib $\alpha$ ectodomain shedding. Thromb. Res. 2013, 132, 696-701. [CrossRef] [PubMed]

82. Brill, A.; Chauhan, A.K.; Canault, M.; Walsh, M.T.; Bergmeier, W.; Wagner, D.D. Oxidative stress activates ADAM17/TACE and induces its target receptor shedding in platelets in a p38-dependent fashion. Cardiovasc. Res. 2009, 84, 137-144. [CrossRef] [PubMed]

83. Choo, H.-J.; Saafir, T.B.; Mkumba, L.; Wagner, M.B.; Jobe, S.M. Mitochondrial calcium and reactive oxygen species regulate agonist-initiated platelet phosphatidylserine exposure. Arterioscler. Thromb. Vasc. Biol. 2012, 32, 2946-2955. [CrossRef] [PubMed]

84. McStay, G.P.; Clarke, S.J.; Halestrap, A.P. Role of critical thiol groups on the matrix surface of the adenine nucleotide translocase in the mechanism of the mitochondrial permeability transition pore. Biochem. J. 2002, 367, 541-548. [CrossRef] [PubMed]

85. Essex, D.W. The role of thiols and disulfides in platelet function. Antioxid. Redox Signal. 2004, 6, 736-746. [CrossRef] [PubMed]

86. Yan, B.; Smith, J.W. A redox site involved in integrin activation. J. Biol. Chem. 2000, 275, 39964-39972. [CrossRef] [PubMed]

87. Verhaar, R.; Dekkers, D.W.; de Cuyper, I.M.; Ginsberg, M.H.; de Korte, D.; Verhoeven, A.J. UV-C irradiation disrupts platelet surface disulfide bonds and activates the platelet integrin $\alpha \operatorname{Ilb} \beta 3$. Blood 2008, 112, 4935-4939. [CrossRef] [PubMed]

88. Mailloux, R.J.; Jin, X.; Willmore, W.G. Redox regulation of mitochondrial function with emphasis on cysteine oxidation reactions. Redox Biol. 2014, 2, 123-139. [CrossRef] [PubMed]

89. Chung, H.S.; Wang, S.-B.; Venkatraman, V.; Murray, C.I.; van Eyk, J.E. Cysteine oxidative post-translational modifications: Emerging regulation in the cardiovascular system. Circ. Res. 2013, 112, 382-392. [CrossRef] [PubMed]

90. Farah, M.E.; Amberg, D.C. Conserved actin cysteine residues are oxidative stress sensors that can regulate cell death in yeast. Mol. Biol. Cell 2007, 18, 1359-1365. [CrossRef] [PubMed]

91. Van der Meer, P.F.; Bontekoe, I.J.; Daal, B.B.; de Korte, D. Riboflavin and UV light treatment of platelets: A protective effect of platelet additive solution? Transfusion 2015, 55, 1900-1908. [CrossRef] [PubMed]

92. Johnson, L.; Winter, K.M.; Reid, S.; Hartkopf-Theis, T.; Marschner, S.; Goodrich, R.P.; Marks, D.C. The effect of pathogen reduction technology (Mirasol) on platelet quality when treated in additive solution with low plasma carryover. Vox Sang. 2011, 101, 208-214. [CrossRef] [PubMed]

93. Carballal, S.; Radi, R.; Kirk, M.C.; Barnes, S.; Freeman, B.A.; Alvarez, B. Sulfenic acid formation in human serum albumin by hydrogen peroxide and peroxynitrite. Biochemistry 2003, 42, 9906-9914. [CrossRef] [PubMed]

94. Jang, J.Y.; Wang, S.B.; Min, J.H.; Chae, Y.H.; Baek, J.Y.; Yu, D.-Y.; Chang, T.-S. Peroxiredoxin II is an antioxidant enzyme that negatively regulates collagen-stimulated platelet function. J. Biol. Chem. 2015, 290, 11432-11442. [CrossRef] [PubMed]

95. Gupta, V.; Carroll, K.S. Sulfenic acid chemistry, detection and cellular lifetime. Biochim. Biophys. Acta 2014, 1840, 847-875. [CrossRef] [PubMed]

96. Paulsen, C.E.; Carroll, K.S. Cysteine-mediated redox signaling: Chemistry, biology, and tools for discovery. Chem. Rev. 2013, 113, 4633-4679. [CrossRef] [PubMed]

97. Chiarugi, P.; Cirri, P. Redox regulation of protein tyrosine phosphatases during receptor tyrosine kinase signal transduction. Trends Biochem. Sci. 2003, 28, 509-514. [CrossRef]

98. Brennan, J.P.; Bardswell, S.C.; Burgoyne, J.R.; Fuller, W.; Schröder, E.; Wait, R.; Begum, S.; Kentish, J.C.; Eaton, P. Oxidant-induced activation of type I protein kinase A is mediated by RI subunit interprotein disulfide bond formation. J. Biol. Chem. 2006, 281, 21827-21836. [CrossRef] [PubMed]

99. Fiaschi, T.; Cozzi, G.; Raugei, G.; Formigli, L.; Ramponi, G.; Chiarugi, P. Redox regulation of $\beta$-actin during integrin-mediated cell adhesion. J. Biol. Chem. 2006, 281, 22983-22991. [CrossRef] [PubMed] 
100. Chiarugi, P.; Pani, G.; Giannoni, E.; Taddei, L.; Colavitti, R.; Raugei, G.; Symons, M.; Borrello, S.; Galeotti, T.; Ramponi, G. Reactive oxygen species as essential mediators of cell adhesion: The oxidative inhibition of a FAK tyrosine phosphatase is required for cell adhesion. J. Cell Biol. 2003, 161, 933-944. [CrossRef] [PubMed]

101. Giannoni, E.; Buricchi, F.; Raugei, G.; Ramponi, G.; Chiarugi, P. Intracellular reactive oxygen species activate Src tyrosine kinase during cell adhesion and anchorage-dependent cell growth. Mol. Cell. Biol. 2005, 25, 6391-6403. [CrossRef] [PubMed]

102. Messens, J.; Collet, J.-F. Thiol-disulfide exchange in signaling: Disulfide bonds as a switch. Antioxid. Redox Signal. 2013, 18, 1594-1596. [CrossRef] [PubMed]

103. Furie, B.; Flaumenhaft, R. Thiol isomerases in thrombus formation. Circ. Res. 2014, 114, 1162-1173. [CrossRef] [PubMed]

104. Cho, J.; Kennedy, D.R.; Lin, L.; Huang, M.; Merrill-Skoloff, G.; Furie, B.C.; Furie, B. Protein disulfide isomerase capture during thrombus formation in vivo depends on the presence of $\beta 3$ integrins. Blood 2012, 120, 647-655. [CrossRef] [PubMed]

105. Janiszewski, M.; Lopes, L.R.; Carmo, A.O.; Pedro, M.A.; Brandes, R.P.; Santos, C.X.C.; Laurindo, F.R.M. Regulation of $\mathrm{NAD}(\mathrm{P}) \mathrm{H}$ oxidase by associated protein disulfide isomerase in vascular smooth muscle cells. J. Biol. Chem. 2005, 280, 40813-40819. [CrossRef] [PubMed]

106. Sefton, B.M. Overview of protein phosphorylation. Curr. Protoc. Cell Biol. 2001. [CrossRef]

107. Immler, D.; Gremm, D.; Kirsch, D.; Spengler, B.; Presek, P.; Meyer, H.E. Identification of phosphorylated proteins from thrombin-activated human platelets isolated by two-dimensional gel electrophoresis by electrospray ionization-tandem mass spectrometry (ESI-MS/MS) and liquid chromatography-electrospray ionization-mass spectrometry (LC-ESI-MS). Electrophoresis 1998, 19, 1015-1023. [PubMed]

108. Zahedi, R.P.; Lewandrowski, U.; Wiesner, J.; Wortelkamp, S.; Moebius, J.; Schütz, C.; Walter, U.; Gambaryan, S.; Sickmann, A. Phosphoproteome of resting human platelets. J. Proteome Res. 2008, 7, 526-534. [CrossRef] [PubMed]

109. Zimman, A.; Titz, B.; Komisopoulou, E.; Biswas, S.; Graeber, T.G.; Podrez, E.A. Phosphoproteomic analysis of platelets activated by pro-thrombotic oxidized phospholipids and thrombin. PLoS ONE 2014, 9, e84488. [CrossRef] [PubMed]

110. Van Marwijk Kooy, M.; Akkerman, J.W.N.; van Asbeck, S.; Borghuis, L.; van Prooijen, H.C. UVB radiation exposes fibrinogen binding sites on platelets by activating protein kinase $C$ via reactive oxygen species. Br. J. Haematol. 1993, 83, 253-258. [CrossRef] [PubMed]

111. Schubert, P.; Culibrk, B.; Coupland, D.; Scammell, K.; Gyongyossy-Issa, M.; Devine, D.V. Riboflavin and ultraviolet light treatment potentiates vasodilator-stimulated phosphoprotein Ser-239 phosphorylation in platelet concentrates during storage. Transfusion 2012, 52, 397-408. [CrossRef] [PubMed]

112. Schwarz, U.R.; Geiger, J.; Walter, U.; Eigenthaler, M. Flow cytometry analysis of intracellular VASP phosphorylation for the assessment of activating and inhibitory signal transduction pathways in human platelets definition and detection of ticlopidine/clopidogrel effects. Thromb. Haemost. 1999, 82, 1145-1152. [PubMed]

113. Fedor, M.; Simonova, R.; Fedorova, J.; Skornova, I.; Duraj, L.; Samos, M.; Stasko, J.; Kovar, F.; Mokan, M.; Kubisz, P. Role of VASP phosphorylation assay in monitoring the antiplatelet therapy. Acta Med. Martiniana 2013, 13, 21-26.

114. Schubert, P.; Coupland, D.; Culibrk, B.; Goodrich, R.P.; Devine, D.V. Riboflavin and ultraviolet light treatment of platelets triggers p38MAPK signaling: Inhibition significantly improves in vitro platelet quality after pathogen reduction treatment. Transfusion 2013, 53, 3164-3173. [CrossRef] [PubMed]

115. Chen, Z.; Schubert, P.; Culibrk, B.; Devine, D.V. p38MAPK is involved in apoptosis development in apheresis platelet concentrates after riboflavin and ultraviolet light treatment. Transfusion 2015, 55, 848-857. [CrossRef] [PubMed]

116. Paulsen, C.E.; Truong, T.H.; Garcia, F.J.; Homann, A.; Gupta, V.; Leonard, S.E.; Carroll, K.S. Peroxide-dependent sulfenylation of the EGFR catalytic site enhances kinase activity. Nat. Chem. Biol. 2012, 8, 57-64. [CrossRef] [PubMed]

117. Yang, J.; Gupta, V.; Carroll, K.S.; Liebler, D.C. Site-specific mapping and quantification of protein S-sulfenylation in cells. Nat. Commun. 2014, 5, 4776. [CrossRef] [PubMed]

118. Lion, N.; Tissot, J.-D.; Prudent, M. Is proteomics still knockin' on the hematological door? Proteomics Clin. Appl. 2016, 10, 765-766. [CrossRef] [PubMed] 
119. Spinella, P.C.; Pidcoke, H.F.; Strandenes, G.; Hervig, T.; Fisher, A.; Jenkins, D.; Yazer, M.; Stubbs, J.; Murdock, A.; Sailliol, A.; et al. Whole blood for hemostatic resuscitation of major bleeding. Transfusion 2016, 56, 190-202. [CrossRef] [PubMed]

120. Johnson, L.; Coorey, C.P.; Marks, D.C. The hemostatic activity of cryopreserved platelets is mediated by phosphatidylserine-expressing platelets and platelet microparticles. Transfusion 2014, 54, 1917-1926. [CrossRef] [PubMed]

121. Johnson, L.; Tan, S.; Wood, B.; Davis, A.; Marks, D.C. Refrigeration and cryopreservation of platelets differentially affect platelet metabolism and function: A comparison with conventional platelet storage conditions. Transfusion 2016, 56, 1807-1818. [CrossRef] [PubMed]

122. Cap, A.P. Platelet storage: A license to chill. Transfusion 2016, 56, 13-16. [CrossRef] [PubMed]

123. Abonnenc, M.; Crettaz, D.; Tacchini, P.; Di Vincenzo, L.; Sonego, G.; Prudent, M.; Tissot, J.-D.; Lion, N. Antioxidant power as a quality control marker for completeness of amotosalen and ultraviolet A photochemical treatments in platelet concentrates and plasma units. Transfusion 2016, 56, 1819-1827. [CrossRef] [PubMed]

124. Tacchini, P.; Lesch, A.; Neequaye, A.; Lagger, G.; Liu, J.; Cortés-Salazar, F.; Girault, H.H. Electrochemical pseudo-titration of water-soluble antioxidants. Electroanalysis 2013, 25, 922-930. [CrossRef]

125. Olas, B.; Wachowicz, B.; Nowak, P.; Kedzierska, M.; Tomczak, A.; Stochmal, A.; Oleszek, W.; Jeziorski, A.; Piekarski, J. Studies on antioxidant properties of polyphenol-rich extract from berries of Aronia melanocarpa in blood platelets. J. Physiol. Pharmacol. 2008, 59, 823-835. [PubMed]

126. Manasa, K.; Vani, R. Influence of oxidative stress on stored platelets. Adv. Hematol. 2016, $2016,4091461$. [CrossRef] [PubMed]

127. Olas, B.; Wachowicz, B. Resveratrol and vitamin C as antioxidants in blood platelets. Thromb. Res. 2002, 106, 143-148. [CrossRef]

128. Sobotková, A.; Mášová-Chrastinová, L.; Suttnar, J.; Štikarová, J.; Májek, P.; Reicheltová, Z.; Kotlín, R.; Weisel, J.W.; Malý, M.; Dyr, J.E. Antioxidants change platelet responses to various stimulating events. Free Radic. Biol. Med. 2009, 47, 1707-1714. [CrossRef] [PubMed]

129. Shen, M.Y.; Hsiao, G.; Liu, C.L.; Fong, T.H.; Lin, K.H.; Chou, D.S.; Sheu, J.R. Inhibitory mechanisms of resveratrol in platelet activation: Pivotal roles of p38 MAPK and NO/cyclic GMP. Br. J. Haematol. 2007, 139, 475-485. [CrossRef] [PubMed]

130. The Effect of Vitamin $E$ and $\beta$ carotene on the incidence of lung cancer and other cancers in male smokers. N. Engl. J. Med. 1994, 330, 1029-1035.

131. Acker, J.P.; Marks, D.C.; Sheffield, W.P. Quality assessment of established and emerging blood components for transfusion. J. Blood Transfus. 2016, 2016, 4860284. [CrossRef] [PubMed]

132. Gerber, B.; Alberio, L.; Rochat, S.; Stenner, F.; Manz, M.G.; Buser, A.; Schanz, U.; Stussi, G. Safety and efficacy of cryopreserved autologous platelet concentrates in. Transfusion 2016, 56, 2426-2437. [CrossRef] [PubMed]

133. Barnard, M.R.; MacGregor, H.; Ragno, G.; Pivacek, L.E.; Khuri, S.F.; Michelson, A.D.; Valeri, C.R. Fresh, liquid-preserved, and cryopreserved platelets: Adhesive surface receptors and membrane procoagulant activity. Transfusion 1999, 39, 880-888. [CrossRef] [PubMed]

134. Italiano, J.E.; Mairuhu, A.T.; Flaumenhaft, R. Clinical relevance of microparticles from platelets and megakaryocytes. Curr. Opin. Hematol. 2010, 17, 578-584. [CrossRef] [PubMed]

135. Roos, M.A.; Gennero, L.; Denysenko, T.; Reguzzi, S.; Cavallo, G.; Pescarmona, G.P.; Ponzetto, A. Microparticles in physiological and in pathological conditions. Cell Biochem. Funct. 2010, 28, 539-548. [CrossRef] [PubMed]

136. Holbrook, L.-M.; Watkins, N.A.; Simmonds, A.D.; Jones, C.I.; Ouwehand, W.H.; Gibbins, J.M. Platelets release novel thiol isomerase enzymes which are recruited to the cell surface following activation. Br. J. Haematol. 2010, 148, 627-637. [CrossRef] [PubMed]

137. Essex, D.W.; Li, M. Protein disulphide isomerase mediates platelet aggregation and secretion. Br. J. Haematol. 1999, 104, 448-454. [CrossRef] [PubMed]

138. Reinhardt, C.; von Brühl, M.-L.; Manukyan, D.; Grahl, L.; Lorenz, M.; Altmann, B.; Dlugai, S.; Hess, S.; Konrad, I.; Orschiedt, L.; et al. Protein disulfide isomerase acts as an injury response signal that enhances fibrin generation via tissue factor activation. J. Clin. Investig. 2008, 118, 1110-1122. [CrossRef] [PubMed]

139. Valeri, C.R.; Macgregor, H.; Ragno, G. Correlation between in vitro aggregation and thromboxane A2 production in fresh, liquid-preserved, and cryopreserved human platelets: Effect of agonists, $\mathrm{pH}$, and plasma and saline resuspension. Transfusion 2005, 45, 596-603. [CrossRef] [PubMed] 
140. Rasongles, P.; Angelini-Tibert, M.F.; Simon, P.; Currie, C.; Isola, H.; Kientz, D.; Slaedts, M.; Jacquet, M.; Sundin, D.; Lin, L.; et al. Transfusion of platelet components prepared with photochemical pathogen inactivation treatment during a Chikungunya virus epidemic in Ile de La Réunion. Transfusion 2009, 49, 1083-1091. [CrossRef] [PubMed]

141. Picker, S.M. Current methods for the reduction of blood-borne pathogens: A comprehensive literature review. Blood Transfus. 2013, 11, 343-348. [PubMed]

142. Henschler, R.; Seifried, E.; Mufti, N. Development of the S-303 pathogen inactivation technology for red blood cell concentrates. Transfus. Med. Hemother. 2011, 38, 33-42. [CrossRef] [PubMed]

143. Mufti, N.A.; Erickson, A.C.; North, A.K.; Hanson, D.; Sawyer, L.; Corash, L.M.; Lin, L. Treatment of whole blood (WB) and red blood cells (RBC) with S-303 inactivates pathogens and retains in vitro quality of stored RBC. Biologicals 2010, 38, 14-19. [CrossRef] [PubMed]

144. Schubert, P.; Culibrk, B.; Karwal, S.; Serrano, K.; Levin, E.; Bu, D.; Bhakta, V.; Sheffield, W.P.; Goodrich, R.P.; Devine, D.V. Whole blood treated with riboflavin and ultraviolet light: Quality assessment of all blood components produced by the buffy coat method. Transfusion 2015, 55, 815-823. [CrossRef] [PubMed]

(C) 2017 by the authors; licensee MDPI, Basel, Switzerland. This article is an open access article distributed under the terms and conditions of the Creative Commons Attribution (CC BY) license (http:/ / creativecommons.org/licenses/by/4.0/). 